\title{
DWARFISM IN EGYPT AND CLASSICAL ANTIQUITY: ICONOGRAPHY AND MEDICAL HISTORY
}

\author{
by \\ VÉRONIQUE DASEN ${ }^{1}$
}

Many aspects of the medical history of the ancient Mediterranean world remain unclear. For many conditions, especially genetic, texts are missing and human remains are scanty. We must rely essentially upon iconography to throw some light on the pathological forms existing in the past, as well as on ancient medical notions. In this paper, I take the example of restricted growth, commonly called dwarfism, a condition characterized by a significantly short stature, over three standard deviations below the mean height of a population of the same age and sex. ${ }^{2}$ The causes of growth disorders are extremely varied (endocrine, metabolic, nutritional), but most types of short stature are due to genetic mutations, which suggests that the birth incidence of dwarfism should be similar in all societies throughout known human history. ${ }^{3}$ The occurrence of the most common disorder, achondroplasia, is of one mutant baby in 34,000 live births, or, if we include related types, of one in 10,000 . When the disorder is due to a dominant genetic mutation, as in achondroplasia, if one parent is

\footnotetext{
${ }^{1}$ Véronique Dasen, Lincoln College, Oxford. Paper read at the Wellcome Unit for the History of Medicine, Oxford, June 1986, and at the Oxford University Anthropological Society, October 1986. The final version has greatly benefited from discussions with $\operatorname{Dr} R$. Wynne-Davies at Oxford and with Dr S. Braga, Inselspital, Berne. I am also very grateful to Prof. J. Baines, Prof. J. Boardman, Dr N. Horsfall, and Dr Smith (Nuffield Hospital) at Oxford, as well as to authors mentioned below for their valuable comments and suggestions. This paper presents some conclusions of my thesis on the status of dwarfs and malformed people in Antiquity, submitted at Oxford University in 1988.
}

ABBREVIATIONS

ABV J. D. Beazley, Attic black-figure vase-painters, Oxford, Clarendon Press, 1956.

ARV $^{2}$ J. D. Beazley, Attic red-figure vase-painters, 2nd ed., Oxford, Clarendon Press, 1963, 3 vols.

$L \ddot{A}$ W. Helck, E. Otto, W. Westendorf (eds.), Lexikon der Ägyptologie, Wiesbaden, Harrassowitz, 1972-1986, 6 vols.

Wb A. Erman, H. Grapow, Wörterbuch der ägyptischen Sprache, repr., Berlin, Akad. Verlag, 1971, 7 vols.

${ }^{2}$ Today, in western countries, most affected persons are between $100 \mathrm{~cm}$ and $140 \mathrm{~cm}$ in height, but some people can be as short as $70 \mathrm{~cm}$. See the standards established by J. M. Tanner, R. H. Whitehouse, and M. Takaishi, 'Standards from birth to maturity for height, weight, height velocity and weight velocity: British children', Arch. Dis. Childhood, 1966, 41: 454-471, 613-635. Compare W. A. Horton, J. I. Rotter, and D. L. Rimoin, 'Standard growth curves for achondroplasia', J. Pediatr., 1978, 93: 435-438; and A.-M. E. Nehme, E. J. Riseborough, and S. J. Tredwell, 'Skeletal growth and development of the achondroplastic dwarf, Clin. Orthop., 1976, 116: 8-23. In this paper, I will use the term "dwarf" frequently, not condescendingly, but as a convenient generic word including mythical, as well as human, short people.

${ }^{3}$ M. D. Grmek, Les maladies à l'aube de la civilisation occidentale, Paris, Payot, 1983, pp.21-30. On future perspectives see A. E. H. Emery and D. L. Rimoin, 'Nature and incidence of genetic disease', in A. E. H. Emery and D. L. Rimoin (editors), Principles and practice of medical genetics, Edinburgh, Churchill Livingstone, 1983, vol. 1, pp. 1-3; and F. Vogel, 'Mutation in man', ibid., pp. 26-48. 


\section{Véronique Dasen}

average-sized, there is one chance in two that the offspring will inherit the disorder. ${ }^{4}$

While ancient texts are scrappy and human remains rare, pictures of short people are extremely numerous and informative. Dwarfism has even probably been the most commonly depicted human physical disorder, since earliest times. My study is based on over a thousand representations of dwarfs (tomb reliefs, vase paintings, mosaics, statuary), which were found in Egypt, Greece, and in the Roman world; they range from the Predynastic Period in Egypt (about 3000 BC) to the end of the Roman Empire (fifth century AD). These pictures can complete the literary sources in two ways. On the one hand, a number of accurately observed pathological forms can be identified. Most previous studies date to the first part of this century and should be revised in the light of present medical nomenclature and of an increasing body of evidence; ${ }^{5}$ during the past decade, medical research has progressively refined the classification of the different types of short stature, which now include over eighty distinct forms. On the other hand, there are a number of iconographic conventions that may limit the realism of the depictions; the rendering of a pathology may be too stylized, or too crude, or it may mix imaginary anomalies (hybrid figures). These iconographic conventions can bring to light ancient folk beliefs that influenced medical understanding. No picture is innocent, no artist is "de bonne foi". The way of stylizing, of selecting relevant features, of misconceiving the rendering of an anatomy, every choice on the artist's part, whether conscious or unconscious, can reveal how the condition was considered in the past. In this perspective, iconography offers us a unique means of approaching the history of collective attitudes and medical notions.

\section{MEDICAL DEFINITION}

Before analyzing ancient depictions, I present briefly the main types of growth disorders known today in order to define the visual features that may allow their identification in art, keeping in mind that ancient writers and artists could not differentiate between very similar conditions and only noted the most striking features of the prototype. ${ }^{6}$

\footnotetext{
${ }^{4}$ R. J. M. Gardner, 'A new estimate of the achondroplasia mutation rate', Clin. Genet., 1977, 11: 31-38; J. L. Murdoch et al, 'Achondroplasia: a genetic and statistical survey', Ann. Hum. Genet., 1970, 33: $227-244$.

${ }^{5}$ See, for example, the studies of $\mathbf{H}$. Meige, 'Les nains et les bossus dans l'art', Nouvelle iconographie de la Salpêtrière, 1896: 161-188; P. Richer, L'art et la médecine, Paris, Gaultier, Magnier, 1901; M. A. Ruffer, 'On dwarfs and other deformed persons in Ancient Egypt', Studies in the palaeopathology of Egypt, University of Chicago Press, 1921, pp. 35-48; W. R. Dawson, 'Pygmies, dwarfs and hunchbacks in Ancient Egypt', Ann. med. Hist., 1927, 9: 315-326; B. Schrumpf-Pierron, 'Les nains achondroplasiques dans l'ancienne Egypte', Aesculape, 1934, 24/9: 223-238; W. R. Dawson, 'Pygmies and dwarfs in Ancient Egypt', JEA, 1938, 24: 185-189; K. R. Weeks, 'The anatomical knowledge of the ancient Egyptians and the representation of the human figure in Egyptian art', PhD diss, Yale University, 1970. More recently, F. N. Silverman, 'De l'art du diagnostic des nanismes et du diagnostic des nanismes dans l'art', J. Radiol., 1982, 63: 133-140.

${ }^{6}$ Select bibliography: D. Bergsma (editor), Birth defects compendium, 2nd ed., London and Basingstoke, Macmillan Press, 1979; V. A. McKusick, Heritable disorders of connective tissue, 4th ed., St Louis, C. V. Mosby, 1972; P. Maroteaux, Diseases of children, Philadelphia, J. B. Lippincott, 1979; H. Moll, Atlas of pediatric diseases, Philadelphia, London, Toronto, W. B. Saunders, 1976; D. L. Rimoin and R. S. Lachman, 'The chondrodysplasias', in Principles and practice of medical genetics, op. cit., note 3 above, pp. 703-735; D. W. Smith, Recognizable patterns of human malformations, 2nd ed., Philadelphia, W. B. Saunders, 1976; R. Smith, 'Disorders of the skeleton', in Oxford textbook of medicine, Oxford, Oxford University Press, 1983, vol. 2, pp. 17, 30-36; J. W. Spranger, L. O. Langer, and H. R. Wiedemann, Bone dysplasias. An atlas of
} 


\section{Dwarfism in Egypt and classical antiquity}

There are two main categories of short stature: a disproportionate type, where restricted growth affects the limbs, or the trunk, or both in varying degrees, and a proportionate type, where the whole body is involved and remains small. In the most frequent types (for example, achondroplasia, hypochondroplasia) men and women seem to be equally affected. The body proportions are defined by the measurement of the upper to lower segment ratios (U/L), taken from the top of head to pubis and from pubis to heel. ${ }^{7}$ Normal adults have an upper/lower segment ratio of approximately 0.95 and an arm span equal to their total height (fig. 1a). The deviation of $U / L$ from the average defines the type of dwarfism present, with short limbs, a short trunk, or a proportionate stature.

\section{DISPROPORTIONATE SHORT STATURE}

Short-limbed dwarfism

The most common type of dwarfism is achondroplasia, a short-limbed disorder due to a dominant genetic mutation that involves the ossification process of the cartilaginous bones, initiated in the uterus. The limb shortening is severe, while the trunk is almost normal in length (fig. $1 \mathrm{~b}$ and plate $1 \mathrm{a}$ ); the head shows a large cranial vault and small facial bones. The prominent forehead is due to the normal development of the cranium from membraneous bone, while the base of the skull ossifies in cartilage and remains shorter: the small foramen magnum may produce hydrocephalus. The nasal bridge is depressed; in later development, protruding jawbones are common. A pronounced pelvic tilt induces lumbar lordosis with very prominent abdomen and buttocks. There may be associated thoracolumbar kyphosis. The finger tips reach only to the top of the thigh (greater trochanter), or even the hips (iliac crest). Joint mobility at the shoulders and the elbows is limited; the arms do not extend normally and fall in a stiffened way to the sides. The legs are short and slightly bowed. Folds of skin are due to the abnormal shortening of the bones. This growth disorder is not associated with metabolic defects, and mental development is usually unimpaired. Physical strength is normal, and agility can be very developed. The genital organs are normal and sexual maturity occurs at the proper time, although the small pelvis may create obstetric problems.

In a milder type, hypochondroplasia, the proportions of the body are similar, but the skull is not involved and the head and the face are normal.

In other types of short-limbed dwarfism, like pseudo-achondroplasia (fig. 1c) or diastrophic dwarfism, the whole skeleton is small and may be affected by severe contractions of the joints, club-foot, and club-hand.

\section{Short-trunk dwarfism}

A disproportionate short stature may also result from an extreme shortening of the trunk due to a flattening of vertebrae, often accentuated by hidden flexion of the hips, coxa vara, and lumbar lordosis. The sternum is protuberant (pectus carinatum). In

constitutional disorders of skeletal development, Philadelphia and Toronto, W. B. Saunders, 1974; R. Wynne-Davies, C. Hall, and A. Graham Apley, Atlas of skeletal dysplasias, Edinburgh, Churchill Livingstone, 1986.

${ }^{7}$ Rimoin and Lachman, op. cit., note 6 above, pp. 705-706. The authors note that Blacks have longer limbs; their $\mathrm{U} / \mathrm{L}$ ratio is of about 0.85 for adults. 


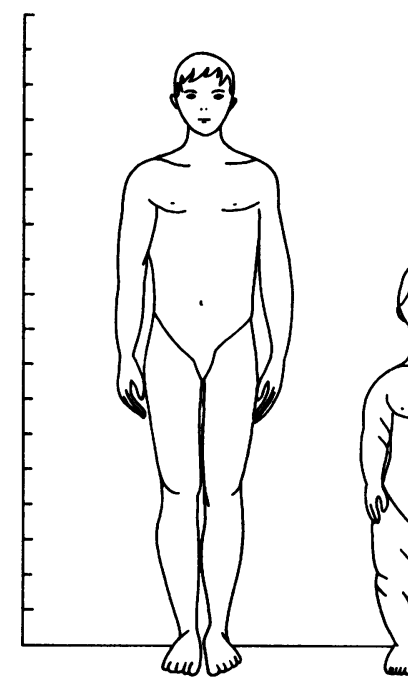

(a) (b) (c)

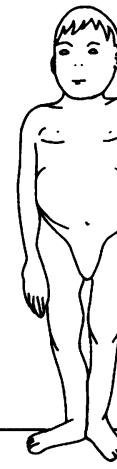

(d)

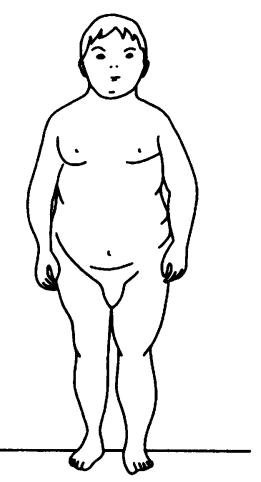

(e)

Figure 1. (a) Normal-sized adult. (b) Achondroplasia. (c) Pseudo-achondroplasia. (d) Spondyloepiphyseal dysplasia congenita. (e) Hypothyroidism.

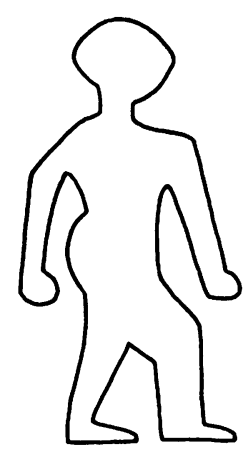

(a)

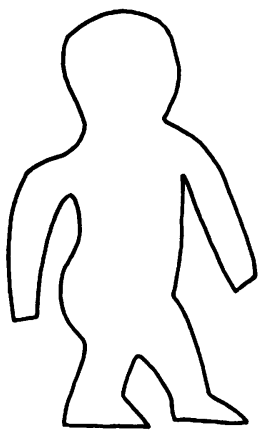

(b)

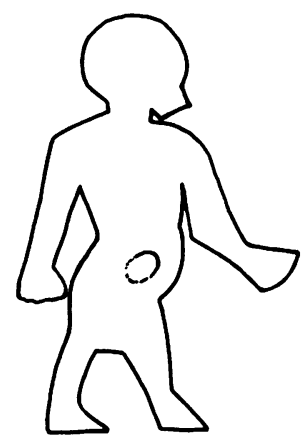

(c)

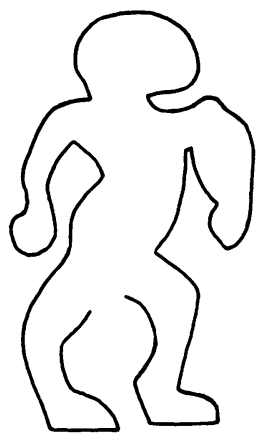

(d)

Figure 2. Sarcophagus of the dwarf Djeho, Late Period, determinative of the term $n m w$. Cairo, Egyptian Museum, CG 29. 307. After A. Tuor's photograph. (b) Tomb of Harkhuf, Aswan, Old Kingdom, determinative of the term dng. After A. Tuor's photograph. (c) Limestone stela, from the cemetery of King Den, First Dynasty (H. $25.5 \mathrm{~cm}$.). Leiden, Rijksmuseum F 1927/1.1. After Museum's photograph. (d) Limestone stela, from the Cemetery of King Djer, First Dynasty (H. $66 \mathrm{~cm}$.). Philadelphia University Museum 9499. After Petrie. 


\section{Dwarfism in Egypt and classical antiquity}

spondylo-epiphyseal dysplasia congenita (fig. 1d), for example, the head is normal and the limbs are approximately normal in length, while in Morquio's syndrome (mucopolysaccharidoses) the facial features are malformed; the nasal bridge is flattened, the wide mouth has thick lips, and jawbones are prominent. Thoracolumbar kyphosis may be present. Walking can be difficult because of hip and leg deformities. Mental retardation is usually minimal or absent.

Pott's disease, a disorder due to tuberculosis of the spine which may cause a shortening of the trunk, and hence restricted growth, should also be mentioned here.

\section{PROPORTIONATE SHORT STATURE}

Dwarfism with proportionate short stature is related to congenital or acquired deficiencies of the pituitary and thyroid glands.

\section{Hypopituitarism}

When the pituitary gland fails to produce growth hormone, the adult has a well-proportioned diminutive stature and a childlike appearance, with a short nose, round cheeks, a small mandible, and a high forehead. Hands and feet are pudgy; the muscles are usually undeveloped, and the trunk tends to a slight obesity. Mental development is usually normal. A secondary hormone deficiency (gonadotropin) may impair sexual development and lead to infantilism.

\section{Hypothyroidism}

A thyroid dysfunction may induce pronounced physical and mental retardation. In severe cases (congenital hypothyroidism) it can lead to complete cretinism. In endemic cretinism, the disorder is associated with goitre and is due to a very low concentration of iodine in drinking-water. The adult retains infantile proportions (in some cases with short limbs), with a distended abdomen accentuated by kyphosis (fig. le). The head is large and shows myxoedema; the face has coarse features, a snub-nose, thick lips, a large protruding tongue, a wrinkled forehead, and an apathetic expression. Sexual maturity is not reached.

\section{Constitutional dwarfism}

Pygmyism enters the same category since the physical features of ethnic "dwarfs" resemble those of persons affected by a growth hormone deficiency. The best-known examples are the pygmy tribes of Central Africa, still living in the forest region in the north-west of Zaire (e.g. the Mbuti) and near the Lake Leopold (e.g. the Twa). Pygmies have a short stature without any disorder of the skeleton. They are thin and muscular, with a lighter skin colour than their negroid neighbours, but similar facial characteristics. Their upper limbs are large in relation to their size, while the volume of their skull and the breadth of their hips are only mildly reduced. The persistence of these specific physical features suggests that pygmyism may be due to a genetic adaptation to the equatorial environment. ${ }^{8}$ Until recently, it was believed that pygmies

${ }^{8}$ L. L. Cavalli-Sforza, 'Studies on African pygmies', Am. J. Genet., 1969, 21: 252-274; idem, 'Biological research on African Pygmies', in G. A. Harrison (editor), Population structure and human variation, Cambridge University Press, 1977, pp. 273-284; J. Hiernaux, 'Long-term biological effects of human 


\section{Véronique Dasen}

had no recognizable hormone deficiency, as their body gave no response to hormone treatment. Recent research has, however, shown that they have a deficiency in an insulin-like growth factor which induces their typical proportionate short stature. ${ }^{9}$

\section{EGYPT}

\section{LITERARY EVIDENCE}

No Egyptian medical text mentions short stature. Derived disorders, such as weakness of the legs, short-sightedness or deafness, are described in medical papyri, but they are never specifically related to a growth disorder. In literature, however, three words designate a dwarf: $n m w, h w^{c}$ and $d n g .{ }^{10}$ They are often accompanied by an explicit determinative (class indicator), which gives us an initial insight into the Egyptian notion of restricted growth.

The term $n m w,{ }^{11}$ commonly translated by "dwarf", is accompanied by the picture of a small man with a long trunk, short limbs, and slightly prominent buttocks suggesting a lordosis, as on the Late Period sarcophagus of the dwarf Djeho (fig. 2a). ${ }^{12}$ The deceased himself had a disproportionate short stature, and is probably depicted at natural size since the figure measures $120 \mathrm{~cm}$ (plate $1 \mathrm{~b}$ ). In the Middle Kingdom tombs of Khety and Bagt I at Beni-Hasan, the word is used as a caption to depictions of short-limbed dwarfs with very short, bowed legs. ${ }^{13}$ The only literary description of a $n m w$ occurs in a New Kingdom magical spell. ${ }^{14}$ A divine dwarf, invoked to avert the danger of fire, is given the physical form of an achondroplastic dwarf: "O you dwarf of heaven! You whose face is big, whose back is long and whose legs are short." The word $h w^{c},{ }^{15}$ which usually denotes shortness and a physical insufficiency, describes here the brievity of the dwarf's legs; in another New Kingdom spell, it also designates the dwarf-god himself. ${ }^{16}$

The term $d n g^{17}$ is similarly associated with the image of a man with short limbs, but it may have meant specifically a "pygmy". The word occurs in the letter sent by King Pepi II (Dyn. 6, c. 2246-2152 BC) to Harkhuf, one of his high officials, governor of

migration from the savanna to the Equatorial forest: a case study of human adaptation to a hot and wet climate', ibid., pp. 187-217.

${ }^{9}$ T. J. Merimee, J. Zapf, and E. R. Froesch, 'Dwarfism in the pygmy', N. Engl. J. Med., 1981, 305, no. 17: 965-968.

${ }^{10}$ See K.-J. Seyfried in $L \ddot{A}$, VI (1986), s.v. Zwerg, col. 1432.

$11 \mathrm{~Wb}, \mathrm{II}$, p. $267,4-6$ (vocalized nemu or nemi).

$12 \mathrm{U} / \mathrm{L}: 1,5$ (determinative of $n m w$ ), U/L: 1,66 (figure of Djeho). H. Gauthier and G. Maspéro, Sarcophages des époques Persane et Ptolémaique, Cairo, Institut Francais d'Archéologie Orientale (CGC), vol. 2, pp. 1-17, plate 22.

${ }^{13}$ For the $n m w$ in the tomb of Khety, see P. E. Newberry, Beni-Hasan, London, Kegan Paul, Trench, Trübner, 1893 (ASE 2), vol. 2, p. 32, plate XVI; Ruffer, op. cit., note 5 above, plate IX, fig. 12; Weeks, op. cit., note 5 above, fig. 12. For the tomb of Bagt I, see Newberry, ibid., p. 36, plate XXXII; Ruffer, ibid., plate IX, fig. 10; Weeks, ibid., fig. 13.

14 Translation by Dawson (1938), op. cit. note 5 above, p. 188; G. Roeder, Der Ausklang der ägyptischen Religion, Zürich und Stuttgart, Artemis Verlag, 1961, pp. 175-177, VII, 9-IX, 5, part U.

${ }_{13} \mathrm{~Wb}$, III, 51-52, 12-17 (vocalized hua).

$16 \mathrm{~J}$. Cerny, and G. Posener, Papyrus hiératiques de Deir el-Médineh, Cairo, Institut Français d'Archéologie Orientale, 1978 (Documents de Fouilles 8), 9-10. See also B. Gunn, 'The Egyptian for "short" ', RT, 1921, 39: 101-104.

${ }^{17} \mathrm{~Wb}, \mathrm{~V}, \mathrm{p} .470,5-7$ (vocalized deneg). 


\section{Dwarfism in Egypt and classical antiquity}

Upper Egypt, who had led an expedition to the southern country of Yam, in the Sudan, and had brought back a small man from the land of the Akhtiu, at the south-eastern limits of the known world. ${ }^{18}$ The king in his letter recalls that the seal-bearer Werdjededba had brought one from Punt (probably in the region of Eritrea) more than a century earlier. ${ }^{19}$ Both $d n g$ seem to be highly praised for their rarity; the king impatiently gives orders to bring him the small man "live, hale, and healthy for the dances of the god ... to delight his heart"; the dng must also be watched on the ship, because he could fall into the river, and his tent must be inspected "ten times at night", which suggests that he could try to escape; the king, who was then aged about eight, may also have expressed an exaggerated solicitude. There is no description of the physical characteristics of the small men; the hieroglyphic determinative shows a standard dwarf with a disproportionate stature, a big head, a long trunk, and short limbs (fig. 2b). Yet, it seems quite likely that these $d n g$ were African pygmies. In present times, most pygmy tribes migrate within the tropical forests and swamps of Central Africa, but they may have lived once farther north in South Sudan. About 1930, for example, P. Crazzolara reported their presence in the marshes of the White Nile on the Bahr el-Arab and Bahr el-Ghazal; ${ }^{20}$ traces of the word $d n g$ may be found in present African vocabularies, as in Amharic denk, which suggests that the word may have been imported into Egypt with the small men. ${ }^{21}$ We know from present reports that Black neighbouring tribes may traditionally keep pygmies in semi-bondage to cultivate their fields, although they respect the small men as "spirits of the forest". ${ }^{22}$ It is thus possible that the people of Yam and Punt offered pygmies to Harkhuf and Werdjededba as precious gifts among other rare products. The pathological form of the figure depicted as a determinative for the word $d n g$ is not really significant. In a Graeco-Roman inscription at Karnak, the same logogram occurs in the word for the "dwarfs" of southern lands (perhaps pygmies?) who bring tribute to Ptolemy VI in a row of Nubian offering-bearers. ${ }^{23}$ This figure is also found as a logogram for

\footnotetext{
18 M. Lichtheim, Ancient Egyptian literature, Berkeley, Los Angeles, and London, University of California Press, 1975, vol. 1, pp. 23-27 (with bibliography). On the half-legendary location of $A k h t i u$, see C. Kuentz, 'Autour d'une conception égyptienne méconnue: l'Akhit ou soi-disant horizon', BIFAO, 1920, 17: 121-190, esp. p. 132 ff. On Yam, see E. Edel, 'Inschriften des alten Reiches. XI. Nachträge zu den Reiseberichten der Hrw-hwf, Z Z̈̈S, 1960, 85: 18-23; and more recently, B. J. Kemp, in B. G. Trigger et al., Ancient Egypt. A social history, Cambridge University Press, 1983, p. $129 \mathrm{ff}$. For another dancing dng, see the Pyramid Texts, utt. 517, § 1189 in e.g. Lichtheim, ibid., p. 48.

${ }^{19}$ On the location of Punt, see K. A. Kitchen in $L \ddot{A}$, IV (1982), s.v. Punt, cols. 1199-1200, and Kemp, op. cit., note 18 above, pp. 136-137.

${ }^{20}$ P. Crazzolara, 'Pygmies on the Bahr el-Ghazal', Sudan Notes and Records, 1933, 16: 85-88. On the location of Pygmies in Antiquity, see C. Préaux, 'Les Grecs à la découverte de l'Afrique', CdE, 1957, 32/64: 286-289; and D. Olderogge, 'Migrations et différenciations ethniques et linguistiques', in Histoire générale de l'Afrique, Paris, UNESCO, 1980, vol. 1, pp. $311 \mathrm{ff}$.

21 I am grateful to D. Dixon for this suggestion. See W. Vycichl, 'Amharique Denk', Annales d'Ethiopie, 1957, 2: 248-249; and Olderogge, op. cit., note 20 above, who adds the forms dank, dinki, donku, dinka. On the possible influence of the image of pygmies in Egyptian religion, see also the collection of African legends in H. F. Wolff, 'Die kultische Rolle des Zwerges im alten Ägypten', Anthropos, 1938, 33: $445-514$.

${ }^{22}$ See P. Crazzolara, op. cit., note 20 above; and, more recently, P. Grielen, 'Pygmées, le grand peuple de la forêt', L'Univers du vivant, 1986, 11: 56-71 (on the Mbuti); and S. Bahuchet, 'Centrafrique, les sept saisons des Aka', ibid., 74-85 (on the Aka).

${ }_{23}$ J. Dümichen, Geographische Inschriften altägyptischer Denkmäler, Leipzig, Hinrichs, 1865, vol. 1, pp. 30-34, plate 31 .
} 


\section{Véronique Dasen}

pathologically short men; in the Old Kingdom titulary of the dwarf Seneb, this hieroglyph is used for "dwarfs" in charge of the linen, who were probably pathological like their supervisor. ${ }^{24}$ Very likely, the Egyptians did not distinguish between indigenous and ethnically short people and used the same standard logogram for both. 25

\section{ICONOGRAPHY}

Egyptian representation has a very rigid system of conventions. The normal human body is shown in its most typical aspect (frontal eye and torso, profile) and has ideal proportions fixed in a canon which may be shown by a squared grid. ${ }^{26}$ The body consists of eighteen, later twenty-one, squares, and is divided into two relatively equal parts. The lower leg (tibia) is slightly longer, and the buttocks smaller than in reality. ${ }^{27}$ The physical form expresses the social status of the figures. Most figures of élite members, kings, and deities are shown in an idealized form, as tall, young, and healthy men; physical irregularities are usually reserved for minor figures involved in specific genre scenes such as marsh-scenes.

In this system, the image of dwarfs became stereotyped very early. From the Predynastic Period (before about 3000 BC) to the Graeco-Roman Period (332 BC), draughtsmen used a similar model made of the physical features of the most common conditions, achondroplasia and hypochondroplasia. A few representations of other types can be also identified. Most depictions come from funerary contexts (tomb reliefs and statuary). ${ }^{28}$

The earliest extant examples of representations of disproportionate dwarfs are small ivory figures found in the Predynastic sites of Ballas and Naqada in Upper Egypt. They represent short-limbed dwarfs, male and female; like normal figures, they are shown standing, naked, with a shaven head and large protuberant ears, with short arms and hands on hips (plate $1 \mathrm{c}){ }^{29}$ They are characterized by strikingly diminutive legs, very bowed, with severe leg deformities (coxa vara). Three ivory figures of female dwarfs found in an Early Dynastic deposit at Hierakonpolis present similar physical characteristics, but two figures are dressed in long skirts and wear bouffant, long-haired wigs. ${ }^{30}$

\footnotetext{
${ }^{24}$ H. Junker, Giza, V, Wien und Leipzig, Hölder, Pichler, Tempsky, 1941 (Österr. Akad. d. Wiss., phil.-hist. Klasse, Denk., 71. Bd., 2. Abh.), pp. 10 and 12 (no. 1), fig. 29.

${ }^{25}$ K. R. Weeks, 'Art, word and the Egyptian world view' in K. R. Weeks (editor), Egyptology and the social sciences, Cairo, American University, 1979, pp. 72-73, has also suggested that the terms dng and $n m w$ might both refer to pathological dwarfs, but distinguished on the basis of social criteria.

${ }^{26}$ See H. Schäfer, Principles of Egyptian art (translated by J. Baines), Oxford, Clarendon Press, 1974; and G. Robins, Egyptian painting and relief, Aylesbury, Shire, 1986.

${ }^{27}$ G. Robins, 'Natural and canonical proportions in Ancient Egyptians', GM, 1983, 61: 17-25.

${ }^{28}$ For material see A. Rupp, 'Der Zwerg in der ägyptischen Gemeinschaft: Studien zur ägyptischen Anthropologie', $C d E, 1965$, 40/79: 260-309; and Weeks, op. cit., note 5 above.

${ }^{29} \mathrm{U} / \mathrm{L}: 2,07$. G. Steindorff, Catalogue of the Egyptian sculpture in the Walters Art Gallery, Baltimore, The Trustees, 1946, p.19, plate 1.3. See also the ivory figurines, ibid., plate $1.2(\mathrm{H} .4 .4 \mathrm{~cm})$ and $1.4(\mathrm{H} .4 .8 \mathrm{~cm}$.); also in W. S. Smith, The art and architecture of Ancient Egypt, Harmondsworth, Pelican History of Art, 1981, fig. 7, pp. 29-30. Also in London, British Museum, 32144 (H. $5.5 \mathrm{~cm}$.), E. A. W. Budge, A guide to the Egyptian collections in the British Museum, London, The Trustees, 1909, pp. 24 and 26, fig. 8.

${ }^{30}$ Oxford, Ashmolean Museum, E 298(H.13.3cm.); B. Hornemann, Types of ancient Egyptian statuary, IV, Copenhagen, Munksgaard, (1951-1969), fig. 881; E 299 (H. $11.9 \mathrm{~cm}$.; unpublished); E 333/346, (H. 15.3 cm),
} 


\section{Dwarfism in Egypt and classical antiquity}

The earliest two-dimensional depictions come from Abydos. The graves surrounding the tombs of the kings of the First Dynasty (c. 2920-2770 BC) produced nine stelae set up for the short people who lived at the court (fig. $2 \mathrm{c}$ and d). ${ }^{31}$ As A. Rupp showed, dwarfs are distinguished by an abnormal pose that stresses their bodily disproportion: while normal adults are depicted sitting, they are shown standing, feet set apart, with very short legs and slightly prominent buttocks due to the pelvic tilt. ${ }^{32}$ Extant skeletal remains confirm the diagnosis made from the pictures. Two dwarfs depicted on stelae from the cemetery of King Semerkhet ${ }^{33}$ may have suffered from achondroplasia, as shown by their very short humeri, thick with broadened ends, and changes to the nasal area of one extant skull. ${ }^{34}$

Most representations of dwarfs date to the Old Kingdom (c. 2575-2134 BC). More than fifty tombs, most of them at Giza and Saqqara, bear pictures of short people tending animals, carrying toilet objects, or making jewellery. Almost all these pictures conform to the same short-limbed model, which may depict achondroplasia when facial changes are present or hypochondroplasia when the face is normal. In the tomb of Mereruka (plate 2c), for example, four disproportionate dwarfs in kilts are making large necklaces. ${ }^{35}$ They are characterized by very long trunks, almost as long as their legs, and extremely short limbs. This disproportion is more pronounced in some other figures, such as the dwarf from the tomb of Mereri (fig. 3b). ${ }^{36}$ Frequently, the lower leg is particularly short and the bowing of the bones is indicated (fig. 3a). ${ }^{37}$ The backs of the dwarf jewellers standing in the tomb of Mereruka show a pronounced lordosis with protruding abdomen and buttocks. Those sitting present peculiar irregularities on the spine, like humps, as do other dwarf jewellers in the tomb of Nufer and Ankhmahor. ${ }^{38}$ These humps may indicate kyphosis, a relatively frequent spine deformity. Their incipient baldness is a feature that often characterizes minor figures (herdsmen, fishermen), but could indicate an achondroplastic bulging forehead. This would, however, be contradictory, since these four dwarfs, as in all the pictures found in tomb and temple reliefs, have perfectly normal faces.

J. E. Quibell, Hierakonpolis, London, B. Quaritch, 1900 (ERA 4), vol. 1, p. 7, plate XI; Ruffer, op. cit., note 5 above, pp. $43-44$, plate $X$, fig. 1 .

${ }^{31}$ For the stela in Leiden, see A. Klasens, OMRO, 1956, 37: 11-34, fig. 5. For the stela in Philadelphia, see W. M. F. Petrie, The Royal tombs of the earliest dynasties, London, Kegan Paul, Trench, Trübner, 1901 (MEEF 21), vol. 2, plates XXVI and XXVIII, no. 58.

${ }^{32}$ Rupp, op. cit., note 28 above, pp. 272-276.

${ }^{33}$ W. M. F. Petrie, The royal tombs of the First Dynasty. London, Kegan Paul, Trench, Trübner, 1900 (MEEF 18), vol. 1, pp. 13, 27, plates XXXI and plate XXXV, nos. 36 and 37.

${ }^{34}$ For radiographs of the skull, see D. R. Brothwell, in D. R. Brothwell and A. T. Sandison (editors), Diseases in Antiquity, Springfield, C. C. Thomas, 1967, pp. 432-433, fig. 8 a; and D. J. Ortner and W. G. Putschar, Identification of pathological conditions in human skeletal remains, 2nd ed., Washington, Smithsonian Press, 1985, pp. 331-332, figs. 518-520. For pictures of the long bones and skull, see also D. Randall-MacIver, The earliest inhabitants of Abydos, Oxford, Clarendon Press, 1901, plate 7.

${ }_{35}$ U/L: 2, 25. P. Duell (editor), The mastaba of Mereruka, University of Chicago Press, 1938 (Oriental Institute Publications 31), vol. 1, plates 29-30, 32-33. See also Ruffer, op. cit., note 5 above, p. 40, plate VIII, fig. 1 .

${ }_{36} \mathrm{U} / \mathrm{L}: 2.9$. W. V. Davies et al., The mastabas of Mereri and Wernu, London, Egypt Exploration Society, 1984 (ASE 36), p. 11, plate 8b.

${ }^{37}$ S. Hassan, Giza, Cairo Government Press, 1943, vol. 4, p. 170, fig. 119 and p. 172, plate XLIX.

${ }^{38}$ For the tomb of Nufer, see A. M. Moussa and H. Altenmüller, The tomb of Nefer and Ka-hay, Mainz am Rhein, Philipp von Zabern, 1971, p. 25, plate 9. For the tomb of Ankhmahor, see A. Badawy, The tomb of 


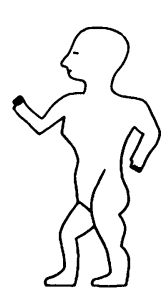

(a)

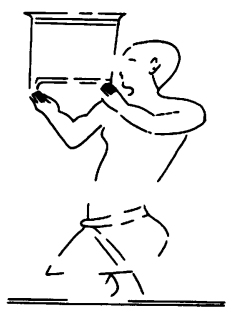

(b)

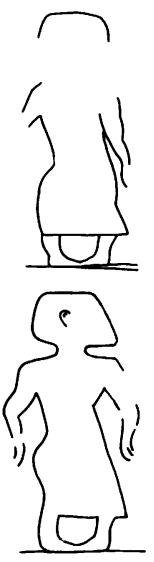

(c)

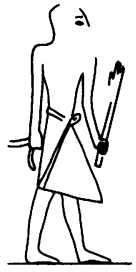

(d)
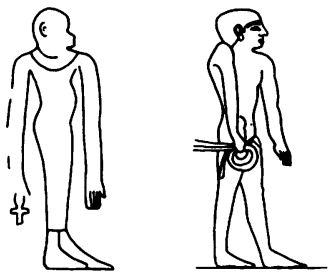

(e)

(f)

Figure 3. (a) Tomb of Debeheni, Giza, Old Kingdom. After A. Tuor's photograph. (b) Tomb of Mereri, Saqqara, Old Kingdom. After W. V. Davies. (c) Tomb of Panehesy, Tell el-Amarna, New Kingdom. After A. Tuor's photograph. (d) Tomb of Ty, Saqqara, Old Kingdom. After A. Tuor's photograph. (e) Obelisk, Late Period. Brooklyn Museum 50. 169. After Museum's photograph. (f) Tomb of Ty, Saqqara, Old Kingdom. After Epron-Daumas.

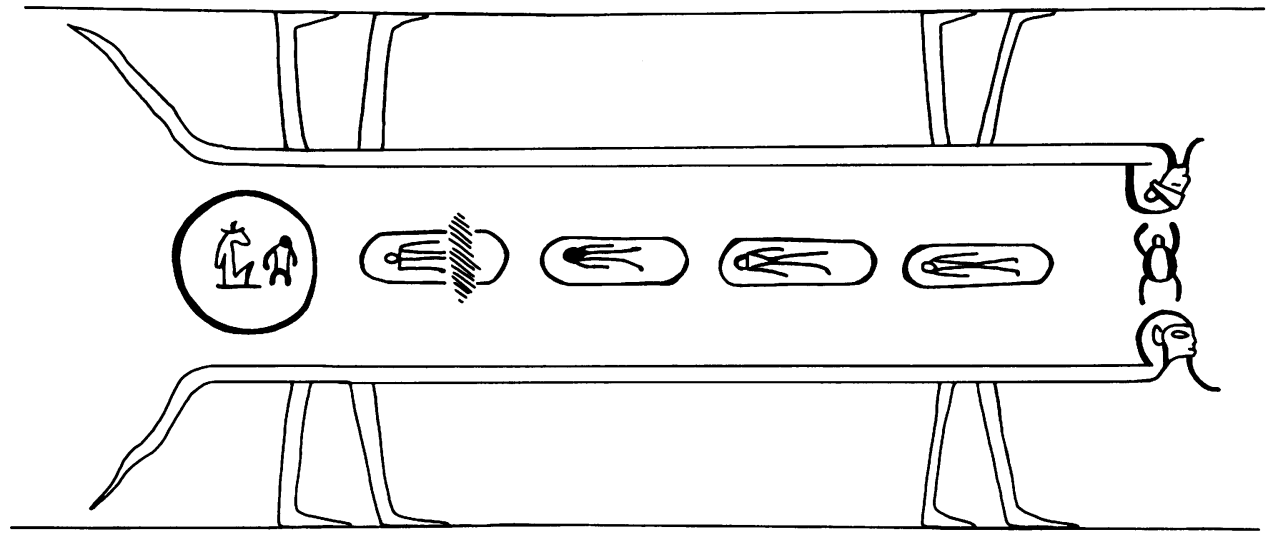

Figure 4. Papyrus Meermanns-Westreenianum 37, The Hague, Dynasty XXI. After Van Voss. 


\section{Dwarfism in Egypt and classical antiquity}

In statuary, short people also have normal facial features, as is the case of the dwarf Seneb, a high functionary at the court of the sixth Dynasty (plate 2a, b) ${ }^{39} \mathrm{He}$ is sitting with his wife, a woman of normal size, while two of his three children are standing in front of his seat at the place of his legs. They do not seem to have inherited their father's disorder. On the false-door of his monument, the artist reproduced the bodily disproportions of Seneb, but followed the standard conventions by making him as tall as his servants, and even sometimes slightly taller, in order to indicate his superior social status. ${ }^{40}$

Middle Kingdom representations show a slight modification of the short-limbed model. Achondroplastic features may be seen in small figurines made of blue glazed ware, who show also curiously flat skull tops, a feature that cannot be explained in medical terms. ${ }^{41}$ This feature is especially characteristic of the figure of the god Ptah in the form of a dwarf, which may have emerged in that period. ${ }^{42}$ Ptah, patron of craftsmen, is primarily known in the form of a well-proportioned adult. From the New Kingdom, and very likely earlier, he was also shown as a dwarf in amulets which were believed to protect children against evil influences (plate 3a). ${ }^{43}$ This dwarf-god, who is also termed Pataikos after Herodotus, ${ }^{44}$ is clearly represented as achondroplastic: he has a long trunk, short bandy legs, a lordosis with a protuberant belly, and a large head with a snub-nose and a flat skull-top, often adorned with a scarab-beetle. ${ }^{45}$ For some scholars, his button-nose and frequent baldness evoke the features of a foetus. ${ }^{46}$ It is more likely that, as a dwarf, Ptah represented youth and old age at the same time. His attributes are often mingled with those of the child Horus, also a powerful protector of children; many figurines show Ptah with a lock of youth hanging on his right shoulder, standing like Horus on crocodiles and holding venomous animals in his hands. Other

Nyhetep-Ptah at Giza and the tomb of Ankhma'ahor at Saqqara, Berkeley, University of California Press, 1978, fig. 32, plate 35 .

39 Junker, op. cit., note 16 above, p. 104 ff., fig. 29, plates VIII-IX; C. Aldred, Egyptian art, London, Thames \& Hudson, 1980, pp. 76-77, fig. 37.

${ }^{40}$ Cairo Museum, JdE 51. 280. Junker, op. cit., note 24 above, plates 5b, 7, 14-15, 18, 20, and 22; U. Fiedler, R. Watermann, 'Über die Zwerge im alten Ägypten', Z. menschl. Vererb- u. Konstitutionslehre, 1956, 33: 509, fig. 4.

${ }^{41}$ See, for example, B. J. Kemp, and R. S. Merillees, Minoan pottery in second millennium Egypt, Mainz am Rhein, Philipp von Zabern, 1980, pp. 138-139, plates 13-14, fig. 44.

42 See the Twelfth Dynasty faience figurine of a dwarf in University College London, Petrie Museum, UC 18745 (H. 5.1 cm.); R. Engelbach and B. Gunn, Harageh, London, Quaritch, 1923 (BSA 28), p. 12, no. 9, plate XIV: his hands are held up, as if in an act of worship.

${ }^{43}$ See, in general, H. Bonnet, Reallexikon der Ägyptischen Religionsgeschichte, Berlin, W. de Gruyter, 1952, s.v. 'Patäke', pp. 584-585; and J. G. Griffiths, in $L \ddot{A}$, IV (1982), s.v. Patäke, cols. 914-915; see also R. Hückel, 'Über Wesen und Eigenart der Pataiken', $Z \ddot{A} S, 1934,70$ : 103-107.

${ }^{44}$ Herodotus, III: 37. For the latest discussion of Herodotus' account, see J. Quaegebeur, W. Clarysse, and B. Van Maele, 'The Memphite triad in Greek Papyri', GM, 1985, 88: 26-32.

${ }^{45}$ For achondroplasia, see Regnault (1914), op. cit., note 5 above, esp. pp. 144-145 (chart comparing real features and artistic rendering); Hückel, op. cit., note 43 above; Schrumpf-Pierron, op. cit., note 5 above, pp. 233-237; T. Dzierzykray-Rogalski, 'La statuette de Ptah-Patèque des collections du Musée Egyptien du Caire', Africana Bulletin, 1970, 13: 109-11. For pseudo-achondroplasia, see Silverman, op. cit., note 5 above, pp. 137-138.

46 P. A. Vassal, 'La physio-pathologie dans le panthéon égyptien: les dieux Bès et Phtah, le nain et l'embryon', Bull. Mém. Soc. d'Anthrop. Paris, 1956, 7: 168-181. 


\section{Véronique Dasen}

Ptah-Pataikoi are characterized as old men with wrinkled foreheads and even beards. ${ }^{47}$

This ambiguous physical appearance had a special meaning in Egyptian religious symbolism. Because of his childlike and malformed appearance, the divine dwarf seems to have embodied one of the various manifestations of the sun god, especially his morning aspect, usually personified by the scarab-beetle Khepri. Thus the dwarf Ptah often wears on his head a scarab-beetle and is given solar qualities in spells. ${ }^{48} \mathrm{~A}$ New Kingdom mythological picture (fig. 4) ${ }^{49}$ suggests that his misshapen silhouette resembled so much the scarab-beetle that he could be substituted for the sacred insect; in the solar disk, a disproportionate dwarf with bowed limbs stands in the place of the normal beetle beside a ram-headed figure symbolizing the evening form of Re. This connexion between dwarfs and sacred beetles outlasted the Pharaonic Period; an astrological text dating to the late-second century AD states that a redoubtable deity induced all kinds of curving processes in man: "this deity [. . . ] produces hunchbacks or makes men bent by sickness, he causes dwarfs to be born and monstrosities ( $\tau \dot{\varepsilon} \rho \alpha \tau \alpha)$ shaped like a beetle, and persons with no eyes, and like a beast and dumb, and dead and toothless ...."50

Other types of dwarfism can also be identified, such as hypothyroidism. Figures of dwarf demons, called Bes as a generic name, appear like Ptah-Pataikos during the Middle Kingdom, and even perhaps earlier; they become extremely popular in the New Kingdom and in the Late Period as familiar protectors (plate $3 b$ ). Like Ptah amulets, Bes-gods ward off danger, and more specifically watch over women's fecundity and sexuality. ${ }^{51}$ Their influence on women may well have been tolerated because no man would regard a misshapen being as a rival. Like disproportionate dwarfs, Bes-gods have large heads, long trunks, and bandy legs. For a few scholars, like F. Regnault, their large squat noses, their protruding tongues and their obesity suggested that their living model was affected by myxoedema. ${ }^{52}$ This diagnosis seems unlikely, since hypothyroidism is usually associated with severe mental and metabolic disorders which do not fit the lively nature of Bes-gods. In fact, apart from the protruding

\footnotetext{
${ }^{47} \mathrm{Cf}$. a figurine of Ptah-Pataikos with a short incised beard in London, British Museum, 11210 (glazed ware; H. $5.3 \mathrm{~cm}$, unpublished).

${ }^{48}$ I am very grateful to Dr Ola El Aguizi in Cairo for discussions on this subject. She has demonstrated these solar connections in magical texts in her dissertation on 'Dwarfs and pygmies in Ancient Egypt' (in Arabic), presented at Cairo University in 1978.

${ }^{49}$ M. Heerma Van Voss, 'Een mythologisch Papyrus in den Haag', Phoenix, 1974, 20: 332-333, fig. 93.

50 The Oxyrhynchus Papyri, ed. with transl. and notes by B. P. Grenfell and A. S. Hunt, London, Egypt Exploration Fund, 1903 (Graeco-Roman branch), vol. 3, no. 465, pp. 126-137, esp. p. 133, col. VIII, lines $225 \mathrm{ff}$.

${ }^{51}$ For material, see F. Ballod, Prolegomena zur Geschichte der zwerghaften Götter in Ägypten, Moskau, H. Liessner, D. Sobko, 1913; and, in general, Bonnet, op. cit., note 43 above, s.v. Bes, pp. 101-109; and $H$. Altenmüller in $L \ddot{A}$, I (1972), s.v. Aha, cols. 96-98, s.v. Bes, cols. 720-724 and ibid., II (1977), s.v. Hit, cols. 1226-1227. For the kinship between Bes and fecundity figures, see J. Baines, Fecundity figures, Warminster, Aris \& Phillips, 1985, pp. 127-131. H. Altenmüller discusses early forms of Bes-gods (Aha) which may go back to the Old Kingdom in 'Die Apotropaia und die Götter Mittelägyptens', Diss. Phil., Munich, 1965, pp. 155 and 164-165.

52 F. Regnault, 'Le dieu égyptien Bès était myxoedémateux', Bull. Soc. d'Anthrop. Paris, 1897, 4ème série, 8: 434-439; idem, 'Les nains dans l'art égyptien', Bull. Soc. franc. Hist. Méd., 1926, 20: 135-150; see also A. Ber,'Déité de l'Egypte ancienne, Bès eut-il pour modèle un nain hypothyroidien?', Organorama, 1973-74, 10, no. 4: 25-30.
} 


\section{Dwarfism in Egypt and classical antiquity}

tongue, Bes-gods conform to the short-limbed model used for Ptah-Pataikos; a bicephalic amulet now in the British Museum $^{53}$ is composed of the figures of Ptah-Pataikos and of Bes back to back; they have distinct heads, but share the same achondroplastic body. The high plumed head-dress of Bes-gods and their facial tattooed patterns led other authors to think that their model was an African pygmy. ${ }^{54}$ In fact, this figure is a hybrid creature that cannot be medically diagnosed. As J. F. Romano has demonstrated, ${ }^{55}$ Bes is probably a native Egyptian creation, clearly composed of human and animal features; he has the proportions of a short-limbed dwarf, mixed with the round ears of a lion, its tail, and perhaps even its ruff, suggested by the short beard around his jawline.

Diastrophic dwarfism, a disorder of the short-limbed type, may be identified in four New Kingdom tombs from Tell el-Amarna (c. 1353-1335 BC). Two dwarfs, dressed in long skirts with strips, are depicted attending the queen's sister Mutbenret; they show a disproportionate short stature with a severe lordosis (fig. 3c). ${ }^{56}$ The intriguing stiff position of their arms, with clubbed hands, and their very bowed legs, with clubbed feet, may be an attempt at rendering the contraction of the joints that characterizes this disorder. They may also be affected by pseudo-achondroplasia, a disorder that may induce such crippling malformations. Diastrophic dwarfism is also characterized by abnormal ear-lobes, large and ossified, as well as by very short lower limbs. An Old Kingdom statue of a dwarf harpist (plate 1d) has such curiously big ears, with swollen lobes, and very small long bones. ${ }^{57}$ However, many Egyptian figures have unusually large ears without any pathological cause, and these details could also be due to a clumsy rendering of the condition.

A few dwarfs with proportionate short stature have been identified. Their small number is partly due to the fact that this disorder is especially difficult to diagnose in iconography; pathologically short men may be confused with minor figures, such as servants or children, shown at a small scale. The draughtsman must stress the physical abnormality of the figure by giving him an adult role or by adding bodily deformities. A case of hypopituitarism may be identified in the tomb of Ty at Saqqara (fig. $3 \mathrm{~d}) .{ }^{58} \mathrm{~A}$ diminutive man leads a dog and a monkey under the palanquin carrying his lord. His body is proportionately reduced, his head normally small and his trunk short. Yet a congenital malformation is suggested by his unusual slimness and by the slight shortening of his legs in relation to his trunk. The figure cannot be confused with that of a child: the dwarf is dressed like an adult, with a pointed kilt, a garment denoting high-ranking servants, he has a name "Pepy", and a title, "leader of the $j w h w$," a term still obscure, but which suggests that the man held a specific office in the household. He

${ }^{53}$ Glazed ware, London, British Museum, 26316 (H. $7.2 \mathrm{~cm}$; unpublished).

${ }^{54}$ L. Keimer, 'Un Bès tatoué?', ASAE, 1943, 42: 159-161.

55 J. F. Romano, 'The origin of the Bes-image', BES, 1980, 2: 39-56.

${ }^{56}$ U/L: 2.1. N. de G. Davies, The rock-tombs of el-Amarna, London, Kegan Paul, Trench, Trübner, 1905 (ASE 12), vol. 2, pp. 13-14, plate V; Ruffer, op. cit., note 5 above, plate IX, fig. 13. $81 \mathrm{~b}$.

57 J. H. Breasted, Egyptian servant statues, New York, Pantheon Books, 1948 (Boll. Ser. XIII), p. 87, plate

${ }^{58}$ L. Epron and F. Daumas, Le tombeau de Ti, Cairo, Institut Français d'Archéologie Orientale, 1939 (Mémoires IFAO 45), vol. 1, p. 18, plate 16; C. Sourdive, La main dans l'Egypte pharaonique, Berne, Peter Lang Verlag, 1984, p. 26, plate IX. 


\section{Véronique Dasen}

is, moreover, depicted in charge of the master's pet animals, a function often reserved for short people. Figures of pituitary dwarfs may also mix with those of disproportionately short people, as in the tomb of the wife of Mereruka, Watekhethor. Twelve female dwarfs with different pathologies walk in a row. Ten of them have disproportionate short stature, with broad shoulders and prominent buttocks, while two are conspicuously slim with a trunk of normal length, like Pepy. All show normal facial features. ${ }^{59}$

A very few dwarf figures show a shortening involving primarily the trunk. I mention the possible depiction of a short-trunk woman on a small obelisk of the Late Period (fig. 3e). ${ }^{60}$ Her profile presents a protruding nose and jawbones, almost simian. Her trunk is very short, with a slight lordosis inducing a prominent belly. Her arms are of unrealistic length and reach mid-tibia. This unusual physical form may represent a racial characteristic, but no positive conclusion can be drawn from the inscription above the figure. $\mathrm{H}$. de Meulenaere relates her name "dg-nt" to the word $d n g$ and suggests that it may mean "dwarf of Neith"; this hypothesis is supported by several New Kingdom references to dwarf-gods associated with the goddess Neith of Sais. ${ }^{61}$

Restricted growth may also be due to Pott's disease, which was probably present in Egypt as early as Predynastic times. ${ }^{62}$ Tuberculous osteomyelitis of the spine may be identified in two figures of dwarfs. The short stature of the man standing with a dwarf in the tomb of Bagt I in Beni-Hasan may be due to that disease. ${ }^{63}$ His neck and his trunk are shortened while his back has a characteristic angular kyphosis. The word that runs above his head, $j w$, may refer to his hump. In the tomb of Ty, a man leading two dogs below a dwarf with a monkey, has a shoulder that makes a curiously protruding angle (fig. 3f). ${ }^{64}$ Yet no conspicuous shortening in the trunk is present, and Pott's disease cannot be identified with certainty.

No skeleton, nor any certain depiction of pygmies, has been found in Egypt. If we assume that the two dng brought back from the south in the time of Kings Izezi and Pepy II were ethnically short, this gap suggests that pygmies were a rarity in Pharaonic times. The only document often quoted as a depiction of pygmies is a toy found in

${ }^{59}$ W. Wrezinski, H. Grapow, and H. Schäfer, Atlas zur altägyptischen Kulturgeschichte, Leipzig, Hinrichs, 1936, vol. 3, plate 11. The small man depicted in the tomb of Ireru at Giza may be another proportionate dwarf (S. Hassan, Giza, Cairo, Government Press, 1941, vol. 3, p. 65, fig. 57, plate XXII) like the woman in the tomb of Amenemhet in Beni Hasan (P. E. Newberry, Beni Hasan, London, Kegan Paul, Trench, Trübner, 1893 (ASE 1), vol. 1, pp. 31 and 37, plate XII) also published in P. Richer, Le nu dans l'art, Paris, Plon, 1925, vol. I, p. 191, fig. 218.

${ }^{60} \mathrm{U} / \mathrm{L}: 0.87$. H. de Meulenaere, 'Un sacerdoce spécifique de Basse-Egypte', $C d E, 1965$, 40/80: 254-255 (no ill.).

${ }^{61}$ See R. el-Sayed, La déesse Neith de Sais, Cairo, Institut Français d'Archéologie Orientale, 1982 (Bibl. d'Etudes 86), vol. 1, pp. 130-131; and Seyfried, op. cit., note 10 above, col. 1433.

62 See D. Morse, D. Brothwell, and P. J. Ucko, 'Tuberculosis in Ancient Egypt', Am. Rev. resp. Dis., 1964, 90: 524-541. See also Grmek, op. cit., note 3 above, pp. 261-266; and K. Manchester, 'Tuberculosis in Antiquity: an interpretation', Med. Hist., 1984, 28: 162-173.

${ }^{63}$ Newberry, op. cit., note 13 above, p. 36, plate XXXII; Ruffer, op. cit., note 5 above, pp. 42-43, plate IX, fig. 15; and Morse, Brothwell, and Ucko, op. cit., note 62 above, p. 526, fig. $3 b$.

${ }^{64} \mathrm{H}$. Wild, Le tombeau de Ti, Cairo, Institut Français d'Archéologie Orientale, 1953, vol. 2, plate CXXVI (Mémoires IFAO 65, 11, 1); Sourdive, op. cit., note 58 above, p. 28, plate X. Also discussed by Morse, Brothwell, and Ucko, op. cit., note 62 above, p. 526, fig. 2c. 


\section{Dwarfism in Egypt and classical antiquity}

el-Lisht, made of ivory (Middle Kingdom, c. 2040-1640 BC) (plate 3c) ${ }^{65}$ Three figures are standing, hands raised, as if dancing, while a fourth one, now in New York, is clapping his hands to beat the rhythm (the figures could be moved by pulling a cord). They have a proportionate short stature, with a slight spinal deformity (prominent buttocks and abdomen) and their wrinkled foreheads suggest that they are old or Pataikos-like. Yet, they do not exhibit clear ethnic characteristics, from which we could conclude that they are pygmies and not short Egyptians. No diagnosis can be drawn from the bowing of their legs, which is due to their dancing; their flat noses may indicate their negroid origin as well as pathological abnormalities.

\section{DISCUSSION}

Throughout the Dynastic Period, Egyptian draughtsmen used a common model to depict dwarfs, a model based upon the features of short-limbed people; even the notion of pygmy was encoded in the script of a disproportionate dwarf. The characteristic features of disproportionate dwarfism are, on the whole, very cleverly observed and selected (the big head, the long trunk in relation to the short bowed limbs). Accurate physical details are often added: the bulging forehead, the muscular trunk, suggested by broad shoulders, the curved and stubby arms with short square hands, the heavy thighs and buttocks, the lordosis induced by the pelvic tilt. The Egyptians recognized other conditions, such as diastrophic dwarfism and proportionate short stature. So far as is known they did not formulate their knowledge in medical texts.

Since the artists used common models, they never made a real portrait. Seneb, for example, is individualized by his titulary and kinship, but his depiction in reliefs and statuary resembles that of other short people. Only the unusual features of the diminutive Pepy in the tomb of Ty and of the two dwarfs from Tell el-Amarna may render the appearance of specific individuals.

The standard form for dwarfs, however, shows three features which are not realistic but have an iconographic meaning: (1) In almost all depictions, short persons have normal faces, which would imply that they are all hypochondroplastics. Since achondroplasia has a similar incidence to hypochondroplasia, this presentation is probably purely conventional. It may be related to the fact that dwarfs are hardly caricatured in Egyptian art. Short persons are most often properly dressed in kilts, which hide the deformity of their legs, while fishermen, for example, wear rough loincloths that reveal their genitals. Even naked dwarfs do not have over-large genitals, or show signs of emaciation; they may have a paunchy belly, a feature that could indicate muscular hypotonia, or rather show that they were well fed and had a good standing in the household. (2) The only sign of caricature is the exaggeration of the small size of dwarfs in most depictions. In tomb reliefs, short persons are shown 1:1.6 smaller than normal adults, or even twice as short. In real size, it means that if an Egyptian man measured 165 to $170 \mathrm{~cm},{ }^{66}$ a dwarf would be as small as $109 \mathrm{~cm}(1: 1.6)$ or even as $87.5 \mathrm{~cm}(1: 1.2)$, which is slightly shorter than in reality (between 100 and

\footnotetext{
${ }^{65}$ E. Brunner-Traut, Der Tanz im alten Ägypten, Glückstadt, Hamburg, and New York, J. J. Augustin, 1938 (Ägyptologische Forschungen 6), p. 35, fig. 12; W. C. Hayes, The scepter of Egypt, Greenwich, Conn., New York Graphic Society, 1968, vol. 1, pp. 222-223, fig. 139.

${ }^{66}$ Robins, op. cit., note 27 above.
} 


\section{Véronique Dasen}

$140 \mathrm{~cm}$ ). This feature probably reveals that smallness was an important part of their attractiveness to the élite who kept them in their households. Their tibiae and fibulae are also often extremely shortened in iconography, while in reality the femur is more affected. ${ }^{67}$ This striking shortness was probably intended by the artist to contrast with the elongated tibia of the normal figures and to emphasize the oddity of dwarf's constitution. (3) As noted above, the flat skull of some figures does not seem to have a medical basis and may be a convention too. It may have been used by artists as a physical attribute stressing the divine affinity of human dwarfs, perhaps in reference to the scarab-beetle adorning the flat skull-top of the dwarf Ptah. The two short servants of the queen's sister at Tell el-Amarna, a place where solar religion was prominent, show such skulls; their exaggerated names (Para, "the Sun", and Erneheh, "To Eternity") emphasize this affinity. ${ }^{68}$ The dwarf Djeho, who also has such a flat skull, was a sacred dancer performing at Athribis and Heliopolis for the burial of the sacred bulls Apis and Mnevis, heralds of Re. ${ }^{69}$

\section{GREECE}

\section{LITERARY EVIDENCE}

In Greece, the image of dwarfs is also simplified: pathological dwarfs, called vãvoi or $\pi v \gamma \mu \alpha i ̃ o i$ are first described by Aristotle in his treatises on natural sciences and physiology. He seems also to have considered disproportionate dwarfism as the archetype of the condition. In the Parts of animals, he defines a dwarf as a person who, like a child, is characterized by an abnormally large upper body, "big in the trunk, or the portion from the head to the residual vent" and a very small lower part "where the weight is supported and where locomotion is effected". ${ }^{70}$ This observation is not fully accurate: Aristotle does not mention the curvature of the limbs, nor the shortening of the arms, nor does he describe any typical facial features. In the History of animals, he adds that dwarfs, like rivvoi, "mules", have over-large genitalia. ${ }^{71}$ For Aristotle, this over-large upper part induces various metabolic disorders: in the Parva naturalia, he explains that dwarfs tend to sleep too much, like children and big-headed people, because the warmth provided by food is cooled by their large upper part and the flowing down of the cold paralyses their system, inducing deep sleep. ${ }^{72} \mathrm{He}$ adds in other passages that their intelligence is not fully developed: the weight of their upper body impairs the working of memory "for weight impairs the motion of the intellect and of general sense". ${ }^{73}$ In the Parts of animals, Aristotle mentions that these intellectual deficiencies are, however, counterbalanced by other qualities, because dwarfs, like children "when compared with adults [. . .], may have some

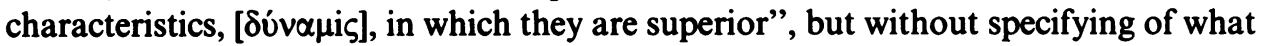

${ }^{67}$ Nehme, Riseborough, and Tredwell, op. cit., note 2 above, p. 17.

${ }^{68}$ Davies, op. cit., note 56 above.

69 Brunner-Traut, op. cit., note 65 above, p. 36.

${ }^{70}$ P.A., IV. 10: 686 b, 1-20 (transl. A. L. Peck, Loeb 1961).

71 H.A., VI. 24: 577 b.

72 Parva naturalia, De somno et vigilia, 457 a 24.

73 P.A., IV. 10: 686 a 30 . See also Parva naturalia, De memoria et reminiscentia, 453 b 1; P.A. IV. 10: 686 b 22. 
kind. ${ }^{74}$ Only in the Problemata, a late compilation of Aristotelian treatises, does the author define clearly two types of dwarfs: short disproportionate persons, who "have limbs of children", a large upper body, and short lower limbs; and people "small as a whole" who look like human miniatures painted on shops. ${ }^{75}$ This proportionate short stature is attributed to a shortage of space. Aristotle tells us that Maltese lap-dogs are reared in small cages that limit their growth; their limbs are progressively crushed and bent. The author does not specify if such treatment could also be applied to humans.

The term $\pi v \gamma \mu \alpha i \tilde{o} \varsigma$ designates also a population of feeble little men, living at the end of the inhabited world, who must each year repel the attacks of migrating cranes. Their name, $\pi v \gamma \mu \alpha i{ }_{0} \varsigma$ derives from $\pi v \gamma \mu \eta$ " "the fist, boxing", and is also a measure of length "from the elbow to the knuckle" (about $33 \mathrm{~cm}$ ), which suggests that they were imagined extremely small and rather pugnacious. ${ }^{76}$ In the late-fifth century, the only author who describes their appearance, Ctesias, locates them in India $;{ }^{77}$ he says that they are very small, with long hair hanging down to the knees, or even longer, and very long beards, so that they do not need any clothing. They are snub-nosed, oiroí, ugly, and men have a very long phallus. ${ }^{78}$

\section{ICONOGRAPHY}

Apart from a series of archaic votive terracottas inspired by the Egyptian dwarf-gods, ${ }^{79}$ pictures of pygmies and pathological dwarfs are found principally in archaic and classical Greek vase painting (sixth to fourth centuries BC) at Athens, but also at Corinth, Thebes, and in South Italy. As in Egypt, they are an exception in Greek iconography: human physical irregularities are normally not shown. Apart from hybrid monsters, only a few mythical figures such as the lame god Hephaistos and the blind hero Teiresias display physical abnormalities. ${ }^{80}$ This suggests that dwarfism was not perceived as an irreducible monstrosity but as a tolerable physical anomaly that did not deprive from human quality. Do these pictures of short-statured people correspond to the definition given by Aristotle? In Greece, as in Egypt, most dwarfs depicted belong to the short-limbed type, but they are rendered with greater attention to details.

The earliest known pictures of dwarfs seem to be those of pygmies, this legendary population of small men always fighting against cranes. The constant mingling of the

74 P.A., IV. 10: 686 b 22.

${ }^{75}$ Problemata, X: 892, 12.

${ }^{76}$ See P. Chantraine, Dictionnaire étymologique de la langue grecque, Paris, Klincksieck, 1968, p. 955; H. Frisk, Griechisches etymologisches Wörterbuch, Heidelberg, C. Winter, 1970, vol. 2, pp. 619-620. For calculations see, for example, $\mathrm{H}$. de Villefosse in Dictionnaire des antiquités grecques et romaines, Paris, Hachette (1877-1910), vol. 4, s.v. Pes, pp. 419-421.

${ }^{77}$ Photius, Bibliotheca, I, 72, 46 a-b.

${ }^{78}$ For the image of pygmies in Greek sources, see P. Janni, Etnografia e mito. La storia dei Pigmei, Rome, Edizioni dell' Ateneo \& Bizzarri, 1978; and A. Ballabriga, 'Le malheur des nains. Quelques aspects du combat des grues contre les pygmées dans la littérature grecque,' REA, 1981, 81: 57-75.

${ }_{79}$ Cf. U. Sinn, 'Zur Wirkung des ägyptischen "Bes" auf die griechische Volksreligion', in Antidoron, Festschrift für J. Thimme, Karlsruhe, C. F. Müller, 1983, pp. 87-94.

${ }^{80}$ On the emergence of portrait, and its corollary the rendering of physical abnormalities, see W. Binsfeld, 'Grylloi, Ein Beitrag zur Geschichte der antiken Karikatur', Diss. Phil., Cologne, 1956; V. Zinserling, 'Physiognomische Studien in der spätarchaischen und klassischen Vasenmalerei', Die griechische 
two terms $\pi v \gamma \mu \alpha i ̄ o s$ and $v \tilde{\alpha} v o \zeta$ can also be observed in iconography. ${ }^{81}$ In Archaic vase-painting, pgymies are not characterized by ethnic features (woolly hair, dark skin), but only by an extreme smallness; they appear as little men, proportionately reduced as on a cup in Würzburg (plate 4a). ${ }^{82}$ In the Classical Period, on red-figure vases, pygmies are depicted like pathological dwarfs with short, bowed limbs, although at this period Greeks knew how to characterize Black people. On a rhyton in Leningrad (plate 4b), the pygmy has typical achondroplastic features, a large head, with snub-nose, a long muscular trunk, thick thighs, and protruding buttocks. A physical abnormality, dwarfism, takes the place of an ethnic characteristic. ${ }^{83}$ This non-ethnic image is, of course, partly related to the fact that the Greeks probably never saw a real pygmy, but could observe their own short compatriots. These pictures of pygmies may also have emerged to account for the presence of dwarfs at Athens; they turned an anomaly into a race in order to reduce its disturbing, exceptional nature. These pictures were thus a means of expressing the trouble induced by this unexplained physical difference, which could be debated freely in ethnological terms. Greek ethnography knew of other fabulous races, similarly distant, which were probably also related to real genetic malformations. An unambiguous example is given by Ctesias, who asserts that "in a distant land called Albania, men are born whose hair turns white in childhood and who see better by night than in the daytime". 84

Images of pathological dwarfs are found mostly in red-figure vase-painting of the second half of the fifth century; their emergence is related to the increasing realism of representation. Disproportionate short stature prevails, and within this category different pathologies are identifiable.

Unlike Egyptian draughtsmen, Greek artists characterized most dwarfs as achondroplastics. On the Peytel aryballos (plate $4 \mathrm{c}$ ), ${ }^{85}$ for example, a short man is standing in a surgery, perhaps waiting for his turn. His morphology is very naturalistically indicated: he has a long, massive trunk, short legs, and thick thighs, with folds of skin, contrasting with the shortness of his lower legs. His hairy chest is made to appear very muscular by the full lower line of the chest muscle (pectoralis major) drawn in brown on his abdomen. His head shows the typical features of

Vase, Wissenschaftliche Zeitschrift der Universität Rostock, 1967, 16: 570-575; and D. Metzler, Porträt und Gesellschaft, Berlin, Wasmuth, 1971.

${ }^{81}$ For material see O. Waser, in W. H. Roscher, Ausführliches Lexicon der griechischen und römischen Mythologie, Leipzig, B. G. Teubner (1902-1909), vol. 3, s.v. Pygmaien, col. 3283-3317; B. FreyerSchauenburg, 'Die Geranomachie in der archaischen Vasenmalerei', in Wandlungen. Studien zur antiken und neueren Kunst, (E. Homann-Wedeking gewidmet), Bayern, Stiftland Verlag, 1975, pp. 76-83.

82 ABV 160. E. Simon, Führer durch die Antikenabteilung des Martin von Wagner Museums der Universität Würzburg, Mainz, Philipp von Zabern, 1975, p. 111, L 414. Only on a gold diadem from Rhodes and on a cup in Berlin do they have a slightly protruding belly. For the diadem, see L. Laurenzi, 'Necropoli Ialisie', Clara Rhodos, 1936, 8: 112-113, figs. 100-101; for the cup in Berlin, Staatliche Museen, F 1785, see Freyer-Schauenburg, op. cit., note 81 above, pp. 78-79, plate $15 \mathrm{c}$.

${ }^{83} \mathrm{ARV}^{2}$ 382, 188. J. Boardman, Athenian red figure vases, London, Thames \& Hudson, 1979, fig. 258. Some archaizing pictures, however, continue to show pygmies as diminutive men. $\mathrm{Cf}$. the pygmies on a fragment of cup in Athens, Agora Museum P 8892; ARV ${ }^{2}$ 587, 63 (unpublished).

84 Aulus Gellius NA, IX, IV, 6 (transl. J. C. Rolfe, Loeb 1948); also in Pliny NH VII, 23 (about India). For a discussion of past and present notion of monstrosity, see F. Gonzalez-Crussi, Notes of an anatomist, London, Picador, 1986, pp. 91-109.

${ }^{85}$ U/L: 2.1. ARV ${ }^{2}$ 813,96. E. Pottier, Une clinique grecque au Ves. Paris, E. Leroux, 1906 (Monuments et Mémoires E. Piot 13), pp. 149-166, plate 13. Boardman, op. cit., note 83 above, fig. 377. 


\section{Dwarfism in Egypt and classical antiquity}

achondroplasia: the depresssion at the root of the nose, emphasized by a large hook drawn at its wing, a bulging forehead, made obvious by his incipient baldness, thick lips, and a strong lower jaw revealed by sparse side-whiskers spread along his cheeks. The abnormal morphology of achondroplastics is often very delicately rendered, as in a figure by the Peleus Painter on a stamnos in Erlangen (plate 4d). ${ }^{86} \mathrm{~A}$ short man, characterized by a broad trunk contrasted with his small arms, dances gracefully. He has a small button-nose, a large lower lip revealed by his moustache and beard, a small chin and mandible contrasting with his large cranium. His bulging forehead is indicated by a fine line towards the eyes, which are surmounted by thick brows giving him a thoughtful expression. In other figures, when the abdomen is in profile, the lumbar lordosis, associated with prominent buttocks and a swelling belly, is clearly indicated. $^{87}$

We know only a few instances of hypochondroplasia. The dwarf depicted on a krater in Zurich, ${ }^{88}$ for example, is distinguished by a perfectly normal profile with a straight forehead-nose line.

The only certain depiction of a pathological proportionate short stature is found on a cup from the Athenian agora (plate 5a). ${ }^{89} \mathrm{~A}$ tiny man with slender limbs hardly reaches the seat of the woman sitting beside him. He has a moustache, painted in diluted glaze, which indicates his adult age, and a strikingly large head, more than a quarter of his size, with a curiously elongated shape. He is probably affected by a pituitary disorder. In other instances, dwarfs may have diminutive proportions, but the depiction is simplified and no precise diagnosis can be made. ${ }^{90}$

An intriguing picture of a dwarf woman in Munich (plate 5b) may be the only example of short trunk $d$ warfism. ${ }^{91}$ She has a very short neck, a stunted trunk with a protruding thoracic cage, and her back is deformed by a pronounced lordosis inducing prominent buttocks. Her arms are of relatively normal length, as her legs would be if they are to be imagined at the bottom of the pot, below the ornament. These features suggest that she is affected by Morquio's syndrome (mucopolysaccharidoses), a disorder associated with metabolic malfunctions which would explain her negroid facial features. This interpretation relies, however, on the addition of her missing lower legs. Her deformity could also be caricature, and not based on observation. Persons affected by this disorder suffer from severe derived complications (limitation of joint mobility, paraplegia), which are not consistent with this woman's appearance of health.

There are some more stylized depictions of dwarfs. No accurate diagnosis is possible, although restricted growth is recognizable. The dwarf jumping and dancing

${ }^{86} \mathrm{ARV}^{2}$ 1039, 6. G. Lippold, 'Zu den Imagines illustrium', $M D A I(R), 1937,52: 44-47$.

${ }^{87}$ See, for example, the dwarfs on a skyphos at Yale University, Stoddart Collection 160, P. V. C. Baur, Catalogue of the R. Darlington Stoddart Collection of Greek and Italian vases in Yale University, New Haven, Conn., Yale University Press, 1922, fig. 13.

${ }^{88}$ Krater Zurich, Arete Gallery, Griechische Schalen und Vasen, liste 20, no. 37.

${ }^{89}$ M. Robertson, 'An unrecognized cup by the Kleophrades Painter?', in K. Schefold, J. Pouilloux, et al, (editors), Stele: Tomos eis Mnemen N. Kontoleontos, Athens, 1980, pp. 125-129, plates 43-44.

${ }^{90}$ See, for example, the dwarf on a chous in Dresden ZV 1827; G. Van Hoorn, Choes and Anthesteria, Leiden, Brill, 1951, p. 125, no. 505, fig. 240.

${ }^{91}$ M. Robertson, 'A muffled dancer and others', in A. Cambitoglou (editor), Studies in honour of A. D. Trendall, Sydney University Press, 1979, pp. 129-134, plate 34, 3 and 4. 


\section{Véronique Dasen}

wildly on a skyphos in Paris (plate 5c), ${ }^{92}$ for example, is proportionately small, but his face resembles that of an achondroplastic person with snub-nose and bulging forehead. In other examples, the heads may be over-large or the facial features unrealistically coarse. ${ }^{93}$

\section{DISCUSSION}

At first, most figures conform to the definition given by Aristotle. Dwarfs are essentially characterized by a striking disproportion between their over-large upper body and their small lower part. Some draughtsmen even neglected to shorten the arms of the dwarfs, an unnecessary element for characterizing the figure, while they emphasized the volume of their heads to make their bodily disproportion more conspicuous. Yet this image of short people differs slightly from that given by Aristotle. Short persons do not seem particularly sleepy, or absent-minded. On the contrary, they are all lively and bustling. Also most of them are not shown with an inordinately large phallus, as asserted in the History of animals. Some dwarfs, however, have a satyr-like relation to women, as in the case of a dwarf dancing with a veiled woman on a pelike in Oxford; ${ }^{94} \mathrm{a}$ winged phallus flies towards the woman, symbolizing the sexual energy of the dwarf. ${ }^{95}$ This privileged affinity with the Dionysiac world is perhaps that special dynamis which, according to Aristotle, distinguished dwarfs from normal men.

As in Egyptian art, none of these pictures is totally naturalistic. I point out here two problematic features that may reflect popular commonplaces about dwarfs: (1) In the Classical Period, almost all Greek dwarfs and pygmies have beards, or moustaches, and a balding head; even pituitary dwarfs have abundant hair, although in reality they are often affected by a gonadotropin deficiency and cannot have secondary sexual characteristics. A rare short-limbed condition, metaphyseal dysplasia, is characterized by such a premature loss of hair, but these hairs are very fine and sparse. The balding heads of Greek dwarfs do not have a medical meaning: they are the visual sign of the affinities of dwarfs with the world of Dionysos and, more specifically, with his male companions, the satyrs. The painters seem often to have accentuated the features that recall the physical oddity of satyrs: like satyrs, dwarfs have thick eyebrows, a depressed nasal bridge, thick lips, and a beard, often associated with incipient baldness. Small satyrs, like the one dancing on a chous from the Agora (plate 5d), ${ }^{96}$ always have abundant hair. The two groups of figures are, however, subtly distinguished: the dwarfs' noses, for example, are usually neatly button-shaped, while those of satyrs are very flat, or irregular, as if broken. The beards of dwarfs are not as large and bushy as those of satyrs, but are usually small and pointed with a few sparse tufts of hair on the cheeks. This hairstyle also characterizes marginal figures such as foreigners, as well as a few Athenian revellers. (2) No representation of a female dwarf has been found, apart

${ }^{92} \mathrm{ARV}^{2}$ 768, 33. P. Ghiron-Bistagne, Recherches sur les acteurs dans la Grèce antique, Paris, Belles-Lettres, 1976, p. 152, figs. 59-60.

${ }_{93}$ Cf. the pelike in Leningrad, Hermitage 740; ARV 1134,11 : F. A. G. Beck, Album of Greek education, Sydney, Cheiron Press, 1975, no. 206, plate 39.

94 Robertson, op. cit., note 91 above, plate 34,1 and 2.

95 On the origin of this folk-belief, see H. A. Shapiro, 'Notes on Greek dwarfs', AJA, 1984, 88: 391-392.

${ }^{96}$ L. Deubner, Attische Feste, Darmstadt, Wiss. Buchgesellschaft, 1962, p. 247, plate 33, 3. 


\section{Dwarfism in Egypt and classical antiquity}

from the one depicted on the skyphos in Munich. The notion of female deformity seems to have been more disturbing than that of male abnormality, which was valued for its dionysiac connections.

\section{ROME}

\section{LITERARY EVIDENCE}

No Hellenistic or Roman medical text mentions restricted growth, but views were probably similar to those expressed by Aristotle. Thus, late lexicographers repeat the belief that dwarfs have large genitalia, like small mules. ${ }^{97}$ In the Empire, high society developed a pronounced taste for entertainers with conspicuous physical or mental malformations, such as cretins, hunchbacks, and dwarfs. A few texts suggest that the market in these people was so good that monsters were artificially produced to satisfy the clientèle. Longinus thus mentions cages in which pygmies or dwarfs were kept in order to stunt their growth, and the elder Seneca says in an imaginary lawsuit that "bonebreakers" collected abandoned children and crippled them, cutting and twisting limbs and bodies to force them to beg in the streets. ${ }^{98}$ Plutarch confirms that in Rome one could buy in the freak-market people "who have no calves or are weasel-armed, or have three eyes, or ostrich-heads." 99

\section{ICONOGRAPHY}

The iconography of the Hellenistic age (from the late-fourth century BC) is characterized by a great increase in numbers of naturalistic subjects. In Alexandria and in Asia Minor, large workshops began to produce a wide range of works depicting human beings with an accentuated physical and psychological realism. Mass production of small terracottas and bronzes, soon distributed throughout the Roman world, gives folk images of the humble people of Hellenistic towns, such as fishermen, merchants, slaves, and beggars. The artists display their virtuosity and their sense of humour in depictions of people in unusual poses, with comic expressions and curious morphologies. ${ }^{100}$

Physical abnormality is no more a taboo, but, on the contrary, picturesque; physical malformation becomes a source of inspiration. In Asia Minor, some workshops produced large numbers of terracottas that show pathological defects very meticulously; these workshops were located in towns with schools of medicine (Smyrna, Pergamum, Ephesos, Alexandria, Cos), and authors like D. and M. Gourevitch have rightly suggested that these workshops did not work for the school, but were probably inspired by observation of the patients who came to consult the doctors. ${ }^{101}$

\footnotetext{
${ }^{97}$ Hesychius, Photius and The Suda, s.v. vãvos.

${ }^{98}$ Longinus, On the sublime, 44, 5; Seneca, Controversiae, 10, 4.

${ }^{99}$ Plutarch, Moralia. On being a busybody, 520 C. Dr. R. Wynne-Davies suggests that people "without calves" might have suffered from phocomelia-a congenital absence of tibia and fibula.

100 On this new imagery, see, for example, N. Himmelmann-Wildschütz, Alexandria und der Realismus in der griechischen Kunst, Tübingen, Wasmuth, 1983, esp. p.70 ff.: J. J. Pollitt, Art in the Hellenistic age, Cambridge (Mass.), Harvard University Press, 1986, esp. pp. 127-149. On the possible influence of physiognomy on the representation of abnormal bodies, see H. P. Laubscher, Fischer und Landleute, Mainz am Rhein, Philipp Von Zabern, 1982, pp. 49-59.

${ }^{101}$ D. and M. Gourevitch, 'Terres cuites hellénistiques d'inspiration médicale', Presse méd., 1963, 71/55: 2751-2752.
} 


\section{Véronique Dasen}

In this period, ordinary dwarfs are depicted with a ruthless realism. Small terracottas and bronzes of dwarfs are common, but they also occur in mosaics and, for pygmies, in wall-paintings. ${ }^{102}$ An artist often emphasized abnormal features in order to create an aesthetic emotion at the expense of his model. The expressions are highly individualized, the attitudes vivid, and the dwarfs' morphology, musculature, and facial features may be rendered with minute attention to details. These works do not form a very homogenous group. The objects have varied origins: some come from the mass production of eastern workshops, while others, finished with great care, were probably made to order and perhaps portray famous dwarfs who belonged to wealthy families as entertainers (musicians, dancers).

Paradoxically, the range of conditions shown is not much wider than in Classical Greece. As always, disproportionate dwarfism prevails, often with typical achondroplastic features, emphasized by grimacing expressions (plate 6a), but the face may also be normal (plate 6b). ${ }^{103}$ In many instances, the phallus is over-large. In Egypt, terracotta figures of old achondroplastic dwarfs may still be related to Ptah-Pataikoi. They are characterized by the head-dress of the child Horus-Harpokrates, with buds on a headband, and have disproportionately large phalluses.

Only a few instances of proportionate short stature can be identified. An example, now in the Louvre, is a woman with a small, plump body (plate $6 \mathrm{c}$ ). ${ }^{104}$

On the other hand, representations of people affected by hypothyroidism are relatively numerous. The majority come from Egypt and Asia Minor and are made in terracotta. They represent humble people, such as fishermen, who are characterized by heavy facial features and obesity. A terracotta in Dresden, for example (plate 6d), shows a dwarf boxer, with cauliflower ears and pathological fatness due to metabolic disorders. ${ }^{105}$

Rarer disorders may have been shown. An ivory figure in the British Museum, for example, shows a crouching hunchback with a stunted trunk and strikingly thin limbs. ${ }^{106}$ He may suffer from metatropic dwarfism, or his limbs may not have grown because of polyomelitis, an infection that affects the spinal cord and induces such destruction of the nerves to the muscles.

102 For material, see W. E. Stevenson, 'The pathological grotesque representation in Greek and Roman art', PhD. diss., University of Pennsylvania, 1975. For a good selection of examples, see also A. Adriani, 'Microasiatici o allessandrini i grotteschi di Mahdia?', $M D A I(R), 1963,70:$ 80-92.

${ }_{103}$ M. B. Comstock and C. Vermeule, Greek, Etruscan and Roman bronzes in the Museum of Fine Arts, Boston, Boston, Mass., Museum of Fine arts, 1971, p. 129, no. 145. For dwarfs with similar grimacing expressions, see, e.g., the three bronze statuettes from Mahdia in Tunis, Bardo (H. 29.5; 31.5 and $32 \mathrm{~cm}$.), Adriani, op. cit., note 102 above, pp. 80-2, plates 32 and 35, 1; For dwarfs with over-large phalluses, see the bronze figurine in Milano, Museo Teatrale alla Scala (H. $12 \mathrm{~cm}$.), Adriani, ibid., 84, plate 37,1 and the bronze figurine in British Museum, London, 1824. 4-31.3 (H. 7.4cm.), Adriani, ibid., plate 37, 2-3. For hypochondroplastics, see, e.g., the bronze statuette in Paris, Petit-Palais, Dut. 40 (H. 7 cm.), Adriani, ibid., p. 85 , plate 38,1 ; and the remarkable bronze athlete in Leiden, Rijksmuseum van Oudheden, K.V. 38 (H. $14.4 \mathrm{~cm}$.), G. Faider-Feytmans, Les bronzes romains de Belgique, Mainz am Rhein, Philipp von Zabern, 1979, vol. 1, p. 128, no. 224, 11, plates 91-93.

${ }_{104} \mathrm{~S}$. Mollard-Besques, Catalogue raisonné des figurines et reliefs en terre-cuite grecs, étrusques et romains, Paris, 1972, vol. 3, p. 70, D 439, plate 95b. Two unpublished bronze figurines of dwarf musicians, sitting, playing the flute, in British Museum, London, 1912. 11-25. 12 (H. $5.4 \mathrm{~cm}$.) and in Ashmolean Museum, Oxford, 1930.300 (H. $5.3 \mathrm{~cm}$.) also have a proportionate short stature.

${ }^{105}$ P. Hermann, 'III. Dresden', A.A., 1891, 4: 167, no. 15. See also the terracotta fisherman in Paris, Louvre, AM $1675+$, Gourevitch, op. cit., note 101 above, fig. 1.

106 British Museum, London, 1814. 7-4. 277 (H. 10.6 cm.), Pollitt, op. cit., note 100 above, p. 138, fig. 148. 

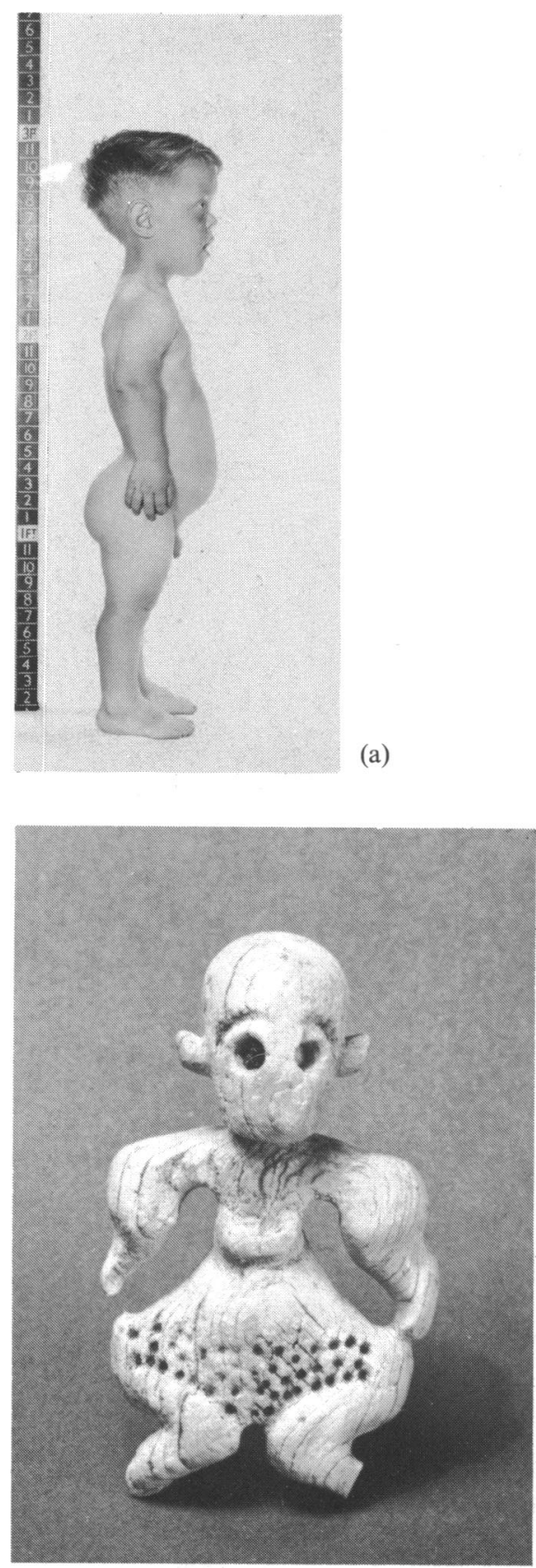

(b)
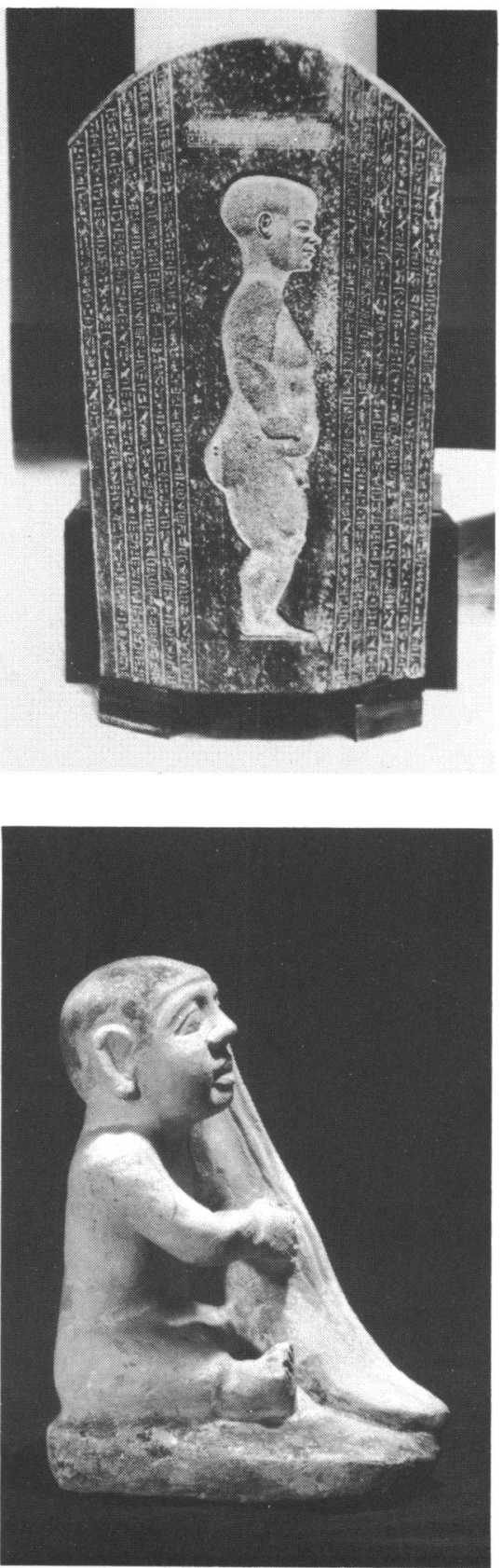

Plate 1. (a) Achondroplastic boy, age 6. Courtesy of Dr C. Hall, Paediatric Radiology at Hospital for Sick Children, Gt. Ormond Street, London. (b) Granite sarcophagus, from Saqqara, Late Period (H. $180 \mathrm{~cm}$, W. $110 \mathrm{~cm}$ ). Cairo, Egyptian Museum, CG 29.307. Courtesy of the Museum. (c) Ivory figurine, from Naqada, Predynastic Period (H. $3.9 \mathrm{~cm}$ ). Baltimore, Walters Art Gallery, 71. 532. Courtesy of the Gallery. (d) Limestone statuette, from the unlocated tomb of Ny-Kau-Inpu, Giza(?), Old Kingdom (H. $12.5 \mathrm{~cm}$ ). University of Chicago, Oriental Institute, 10641. Courtesy of the Oriental Institute. 

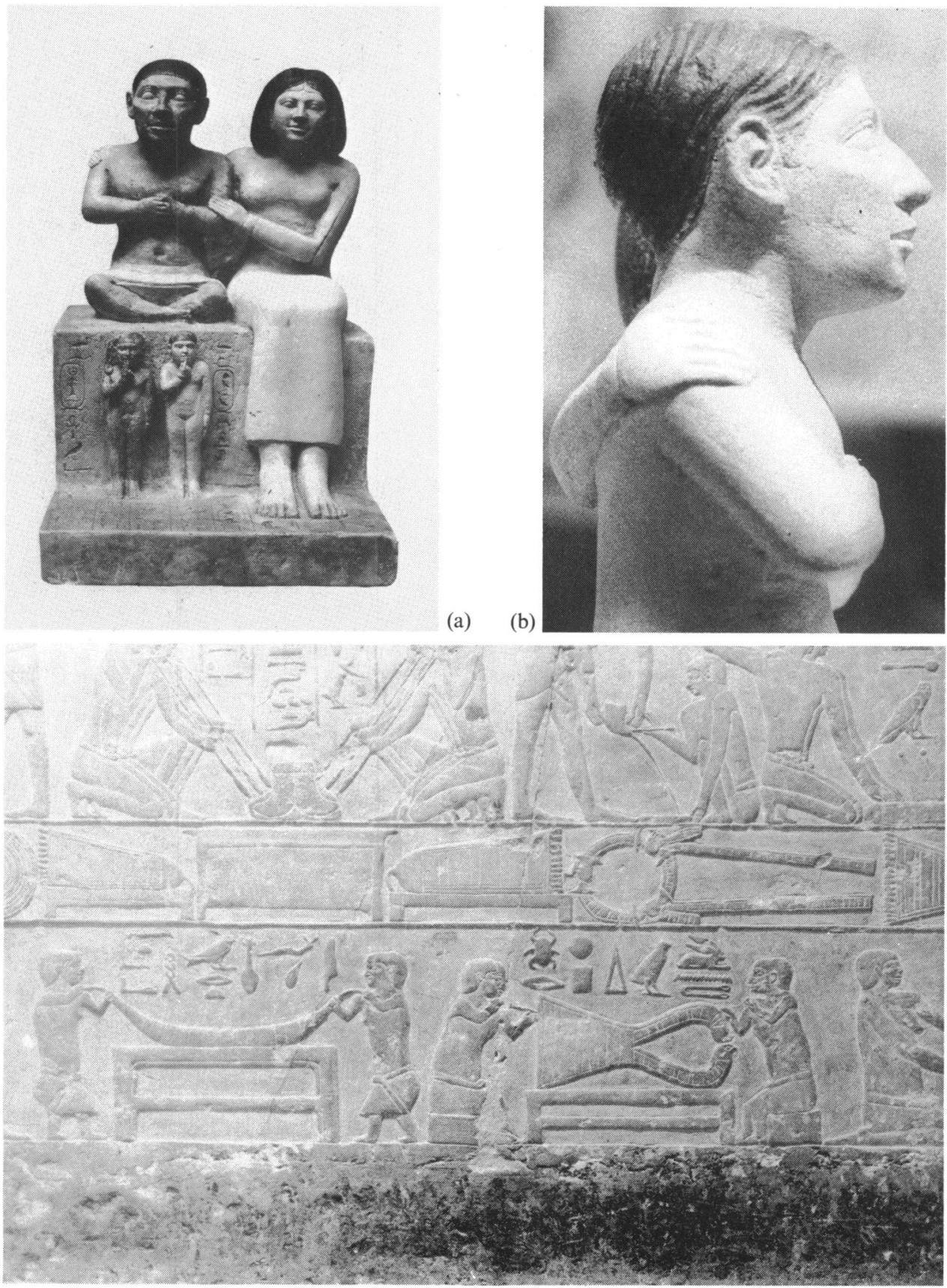

(c)

Plate 2. (a) Limestone group of Seneb and his family, from Giza, Old Kingdom (H. $33 \mathrm{~cm})$. Cairo, Egyptian Museum, JdE 51. 281. Courtesy of the Museum. (b) Detail of Seneb. Photo A. Tuor. (c) Tomb of Mereruka, Saqqara, Old Kingdom. Photo A. Tuor. 

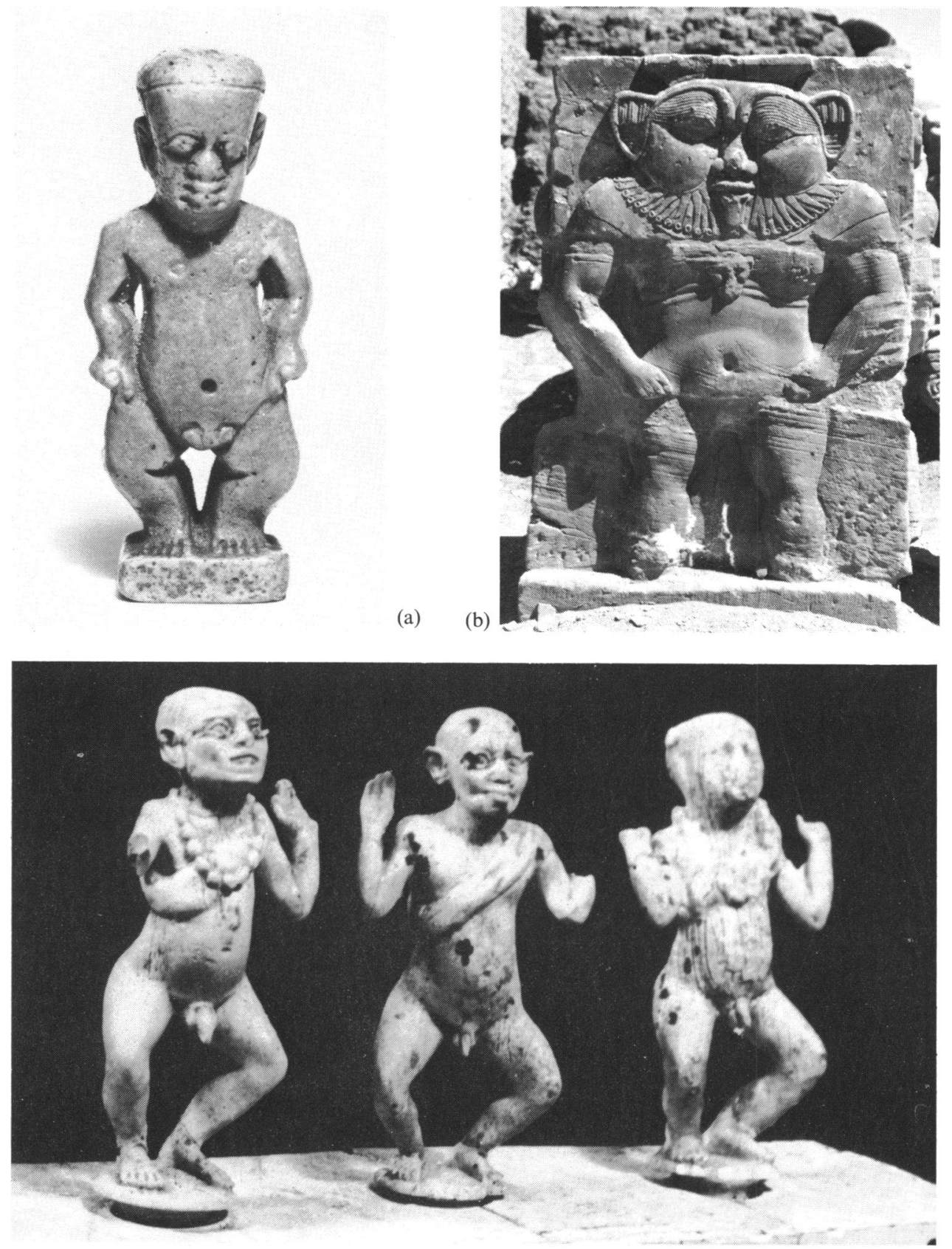

(c)

Plate 3. (a) Faience figurine of Ptah, Late Period (H. $8.5 \mathrm{~cm})$. Oxford, Ashmolean Museum, Queen's College Loan 332. Courtesy of the Visitors of the Ashmolean Museum. (b) Limestone figure of Bes, Dendarah, Graeco-Roman Period. Photo A. Tuor. (c) Ivory group from el-Lisht, Middle Kingdom (H. $6.5 \mathrm{~cm}$ ). Cairo, Egyptian Museum, JdE 63. 858. Courtesy of the Museum. 

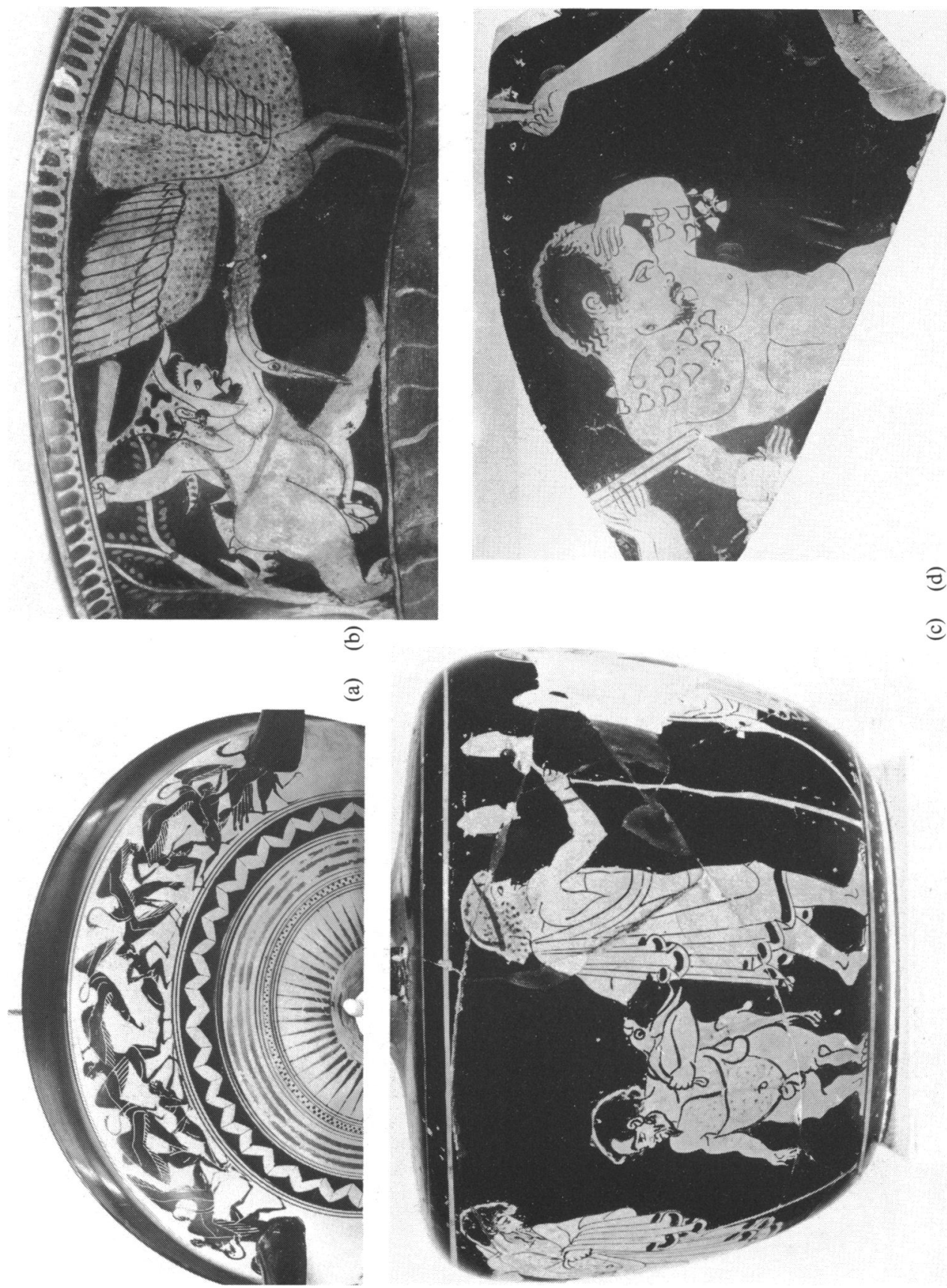

Plate 4. (a) Cup, c. 550 BC. Würzburg, Martin Von Wagner Museum der Universität Würzburg, L 414. Courtesy of the Museum. (b) Rhyton, $c .480$ BC. Leningrad, Hermitage, b 1818 (679). Courtesy of the Museum. (c) Aryballos, c. 480 BC. Paris, Louvre, CA 2183. Courtesy of the Museum. Photo Chuzeville. (d) Stamnos, fr., c. 450-440 BC. Erlangen Universität, Institut für Altertumskunde, I707. Courtesy of the Institute. 


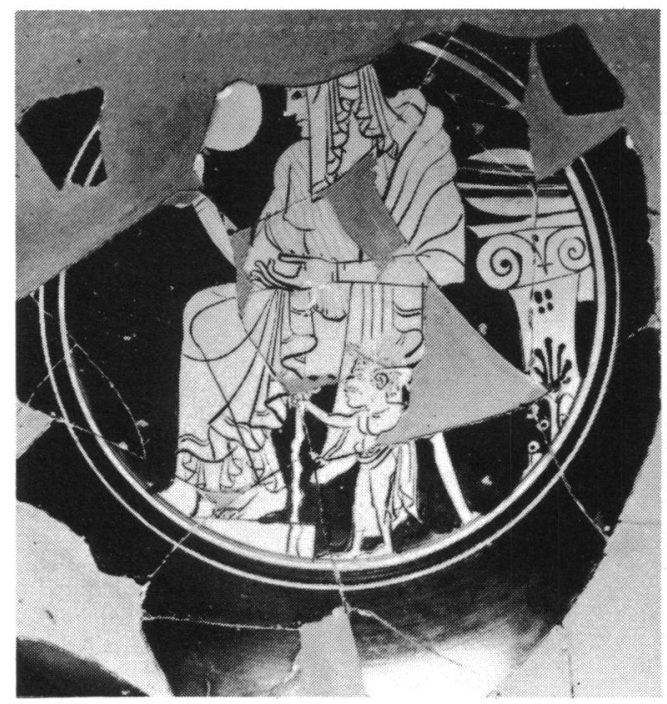

(a)
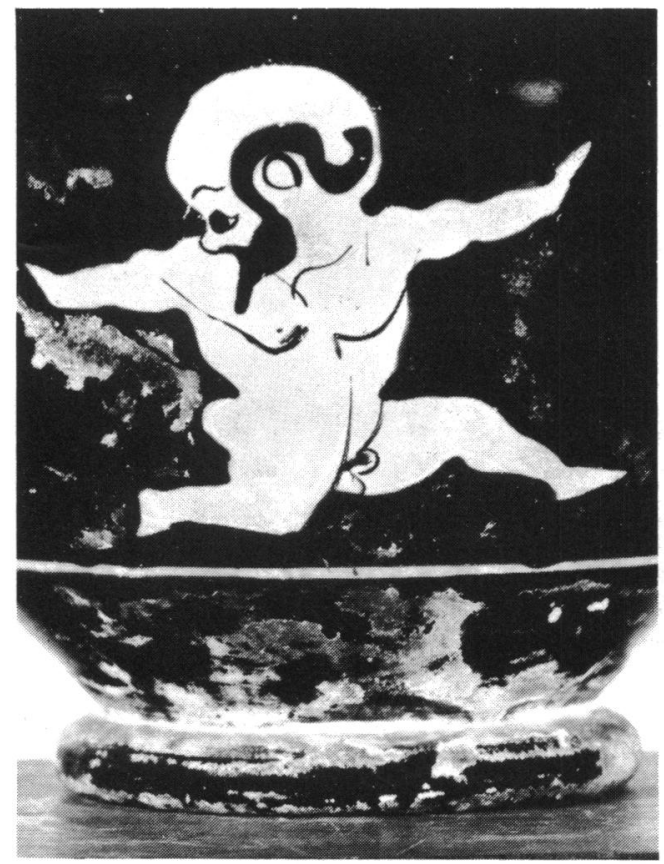

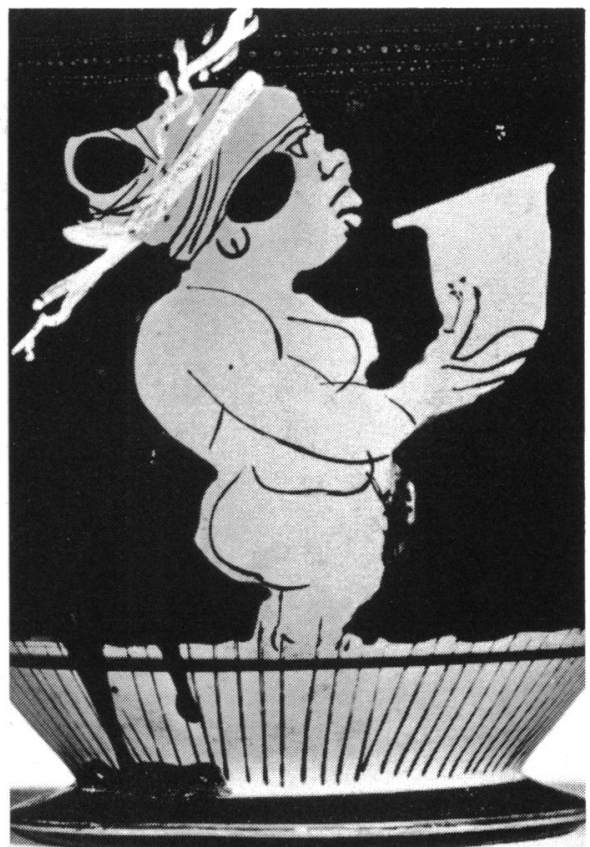

(b)

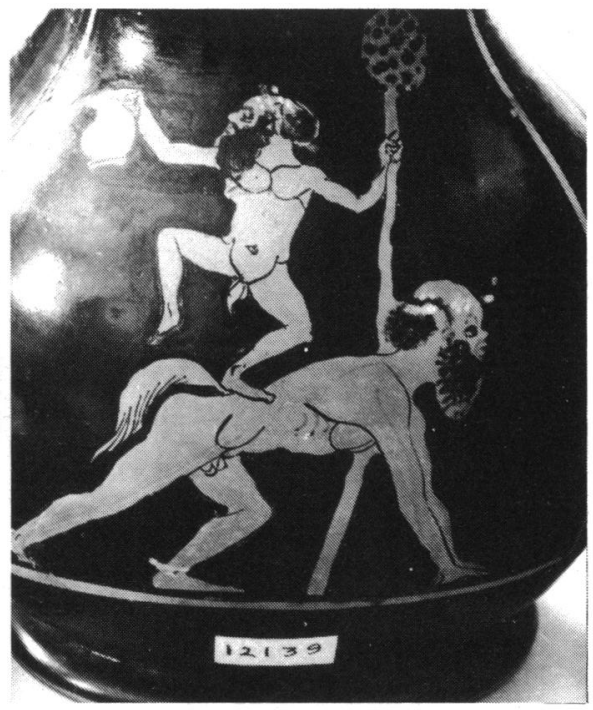

(d)

Plate 5. (a) Cup, c. 500-475 BC. Athens, Agora Museum, P 2574. Courtesy of Agora Excavations, American School of Classical Studies at Athens. (b) Kotyle, c. 430-420 BC. Münich, Staatliche Antikensammlungen und Glyptothek, 8934. Courtesy of the Museum. (c) Skyphos, c. 450 BC. Paris, Louvre, G 617. Courtesy of the Museum. Photo Chuzeville. (d) Chous, c. 450-440 BC. Athens, National Museum, 12139. Courtesy of the Museum. 


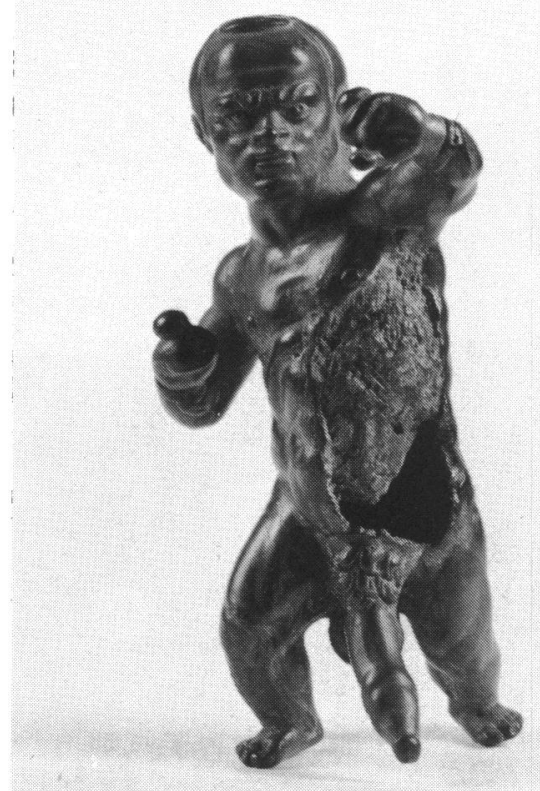

(a)

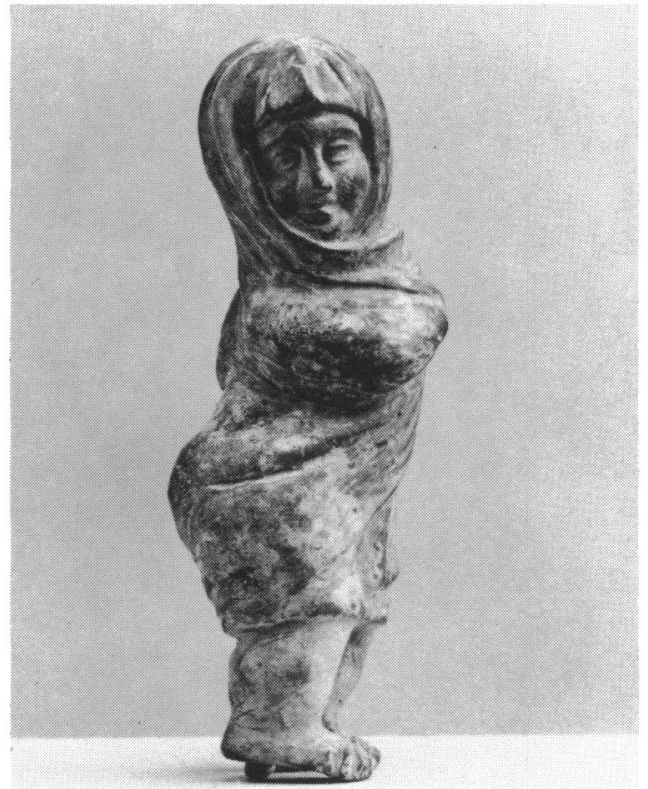

(c)

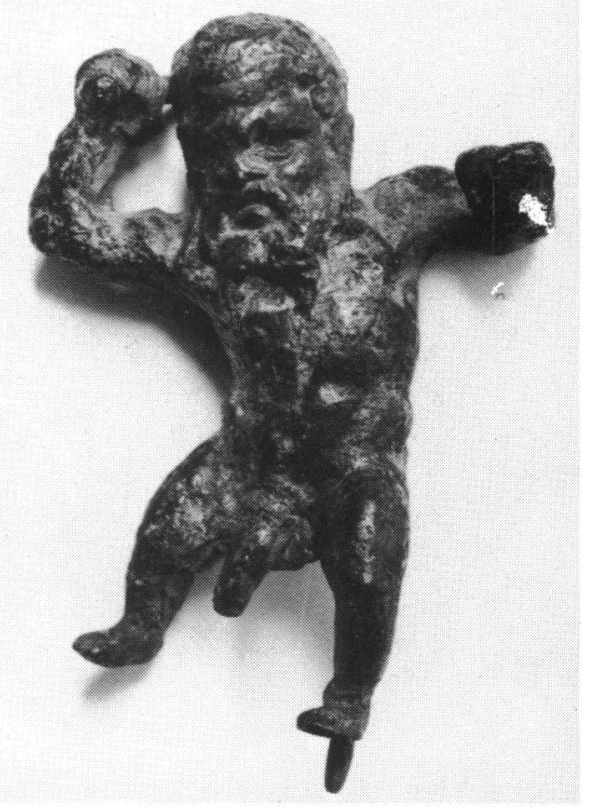

(b)

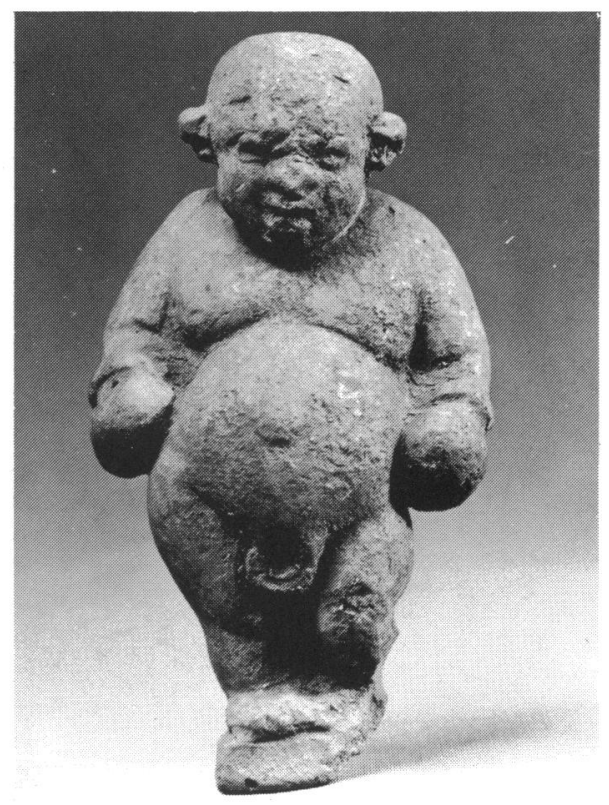

(d)

Plate 6. (a) Bronze statuette, Hellenistic period (H. $11.1 \mathrm{~cm})$. Boston, Museum of Fine Arts, $08.32 \mathrm{k}$. Courtesy of the Museum. (b) Bronze statuette, Hellenistic period (H. $5.8 \mathrm{~cm})$. British Museum, London, 1772. 3-2. 96. Author's photograph. (c) Terracotta statuette, Hellenistic period (H. $9 \mathrm{~cm})$. Paris, Louvre, CA 480. Courtesy of the Museum. Photo Chuzeville. (d) Terracotta statuette, Hellenistic period (H. $10 \mathrm{~cm})$. Dresden, Staatliche Kunstsammlungen, ZV 803. Courtesy of the Museum. 


\section{Dwarfism in Egypt and classical antiquity}

Pygmies are shown mostly in mosaics and wall-paintings depicting so-called Nilotic landscapes. ${ }^{107}$ Their short-limbed bodies are painted in dark colours and caricatured by grotesque over-large phalluses. As $\mathrm{H}$. Whitehouse has demonstrated, the Romans may have identified some of these figures with Ptah-Pataikoi: they have side-locks and hold in each hand sticks recalling the snakes strangled by Ptah-Pataikoi and by Ho as-Harpokrates. ${ }^{108}$

\section{DISCUSSION}

Hellenistic and Roman imagery shows very precise anatomical details, but this accuracy is counterbalanced by a strong tendency to caricature. Abnormal features are emphasized or added in order to create a grotesque effect. Thus, short people often have inordinately large phalluses, grimacing faces, and very contorted attitudes. This paradox may be explained in part by the special sense of humour of the ancient Romans, who were attracted by physical malformations. ${ }^{109}$ Dwarf entertainers are caricatured to enhance their attractiveness and playfully mimic characters of everyday life.

Ancient popular beliefs in the apotropaic qualities of the phallus and of malformed people may also account for this tendency to exaggeration. Misshapen people, such as hunchbacks, were credited with the power of repelling malevolent influences because their deformity attracted the evil eye. ${ }^{110}$ Short people were probably made ugly to increase these apotropaic qualities. As many Hellenistic figures originate from Egypt, their overlarge phalluses may be a reminiscence of the native belief in the influence of the dwarf gods, especially Bes, over female sexuality and fertility, but expressed in a new iconography. ${ }^{11}$

\section{CONCLUSION}

Although literary evidence is very scanty, iconography shows that in these three cultures growth disorders always attracted attention and were carefully observed: the two main types of short stature are distinguished (disproportionate/proportionate). A few rarer types are also depicted, such as diastrophic dwarfism and hypopituitarism. None of these cultures presented restricted growth as a handicap. On the contrary, short people always appear very active, even those with club-feet: they are skilful jewellers, they may carry chests and other large objects, they run with dogs, train in the

${ }^{107}$ For material, see J.-P. Cèbe, La caricature et la parodie dans le monde romain antique des origines à Juvénal, Paris, E. De Boccard, 1966 (BEFAR 206), pp. 345-354; and H. Whitehouse, Nilotic landscapes in Roman art, forthcoming British School at Rome Supplement.

${ }^{108}$ H. Whitehouse, 'In Praedis Iuliae Felicis', Papers of the British School at Rome, 1977, 45: 52-68, and esp. pp. 65-68 on pygmies' religious connotations.

109 Cèbe, op. cit., note 107 above, pp. 354-359.

${ }^{110} \mathrm{D}$. Levi, 'The evil eye and the lucky hunchback', in Antioch-on-the-Orontes, Princeton, 1941, pp. 228-29, plate 56; A. J. B. Wace, 'Grotesques and the Evil eye', BSA, 1903-4, 10: $103-114$ (contra: G. M. A. Richter, 'Grotesques and the Mime', $A J A, 1913,17$ : 149-156); Stevenson, op. cit., note 102 above, (with bibliography). See also the general survey of A. and J. Knuf, Amulette und Talismane, Cologne, Dumont, 1984.

${ }^{111}$ A very late Egyptian magical stela (3rd-4th century AD) invokes the protection of Bes over feminine sexual organs. See G. Michailidis, 'Le dieu Bès sur une stèle magique', BIE, 1960-62, 42-43: 65-68. 
gymnasium, and often dance with great vivacity. In the iconography of these three cultures, short-limbed dwarfism (achondroplasia and hypochondroplasia) prevails. This preponderance may reflect reality since the incidence rate of achondroplasia and of hypochondroplasia is the highest of all types of dwarfism; affected newborn infants are also relatively strong.

Yet each culture developed slightly different detailed models: some real physical features are enhanced, as if they became more significant, others are suppressed. Thus in Pharaonic Egypt, dwarfs are characterized by normal faces associated with very short limbs, but by snub-noses associated with balding heads in Classical Greece, while an over-large phallus is a common feature in the Hellenistic and Roman world. These iconographic choices cannot be explained by medical causes and they do not reflect the progress of scientific knowledge. More probably, they express the different social roles given to that physical minority throughout the centuries: dwarfs received a positive evaluation in Egypt (affinity with the sun god) and in Greece (affinity with satyrs and the Dionysiac world), but in Rome only their apotropaic and entertaining qualities prevailed. Gaps in the material are revealing too. The absence of dwarf women in Greek imagery suggests that the notion of female physical abnormality was not acceptable in Athens. Male dwarfs were symbolically made acceptable by their integration within the Dionysiac cult. Their physical anomaly seems to have been regarded as the sign of an immediate relationship with the world of Dionysos and made them a human counterpart of satyrs. This absence of women may also bear witness to some sympathetic feelings; their representation would have implied making them objects of popular derision, as may have happened with the woman on the Munich skyphos. 